Cover photograph: View of the Deshka River on June 26, 2001, by Robert Ourso, U.S. Geological Survey. 


\section{Water Temperature of Streams in the Cook Inlet Basin, Alaska, and Implications of Climate Change}

By REBECCA E. KYLE and TIMOTHY P. BRABETS

Water-Resources Investigations Report 01-4109

Prepared as part of the NATIONAL WATER-QUALITY ASSESSMENT PROGRAM 


\section{U. S. DEPARTMENT OF THE INTERIOR}

GALE A. NORTON, Secretary

U.S. GEOLOGICAL SURVEY

CHARLES G. GROAT, Director

The use of trade, product, or firm names in this publication is for descriptive purposes only and does not imply endorsement by the U.S. Government.

For additional information:

\section{District Chief}

U.S. Geological Survey

4230 University Drive, Suite 201

Anchorage, AK 99508-4664
Copies of this report may be purchased from:

U.S. Geological Survey

Branch of Information Services

Box 25286

Denver, CO 80225-0286

Internet URLs:

Alaska Water Resources: http://ak.water.usgs.gov

Cook Inlet Basin NAWQA: http://ak.water.usgs.gov/Projects/Nawqa/

National NAWOA: $\quad$ http://water.usgs.gov/nawqa/nawqa_home.html 


\section{FOREWORD}

The U.S. Geological Survey (USGS) is committed to serve the Nation with accurate and timely scientific information that helps enhance and protect the overall quality of life, and facilitates effective management of water, biological, energy, and mineral resources. Information on the quality of the Nation's water resources is of critical interest to the USGS because it is so integrally linked to the long-term availability of water that is clean and safe for drinking and recreation and that is suitable for industry, irrigation, and habitat for fish and wildlife. Escalating population growth and increasing demands for the multiple water uses make water availability, now measured in terms of quantity and quality, even more critical to the long-term sustainability of our communities and ecosystems.

The USGS implemented the National WaterQuality Assessment (NAWQA) Program to support national, regional, and local information needs and decisions related to water-quality management and policy. Shaped by and coordinated with ongoing efforts of other Federal, State, and local agencies, the NAWQA Program is designed to answer: What is the condition of our Nation's streams and ground water? How are the conditions changing over time? How do natural features and human activities affect the quality of streams and ground water, and where are those effects most pronounced? By combining information on water chemistry, physical characteristics, stream habitat, and aquatic life, the NAWQA Program aims to provide science-based insights for current and emerging water issues. NAWQA results can contribute to informed decisions that result in practical and effective water-resource management and strategies that protect and restore water quality.

Since 1991, the NAWQA Program has implemented interdisciplinary assessments in more than 50 of the Nation's most important river basins and aquifers, referred to as Study Units. Collectively, these Study Units account for more than 60 percent of the overall water use and population served by public water supply, and are representative of the Nation's major hydrologic landscapes, priority ecological resources, and agricultural, urban, and natural sources of contamination.

Each assessment is guided by a nationally consistent study design and methods of sampling and analysis. The assessments thereby build local knowledge about water-quality issues and trends in a particular stream or aquifer while providing an understanding of how and why water quality varies regionally and nationally. The consistent, multi-scale approach helps to determine if certain types of water-quality issues are isolated or pervasive, and allows direct comparisons of how human activities and natural processes affect water quality and ecological health in the Nation's diverse geographic and environmental settings. Comprehensive assessments on pesticides, nutrients, volatile organic compounds, trace metals, and aquatic ecology are developed at the national scale through comparative analysis of the Study-Unit findings.

The USGS places high value on the communication and dissemination of credible, timely, and relevant science so that the most recent and available knowledge about water resources can be applied in management and policy decisions. We hope this NAWQA publication will provide you the needed insights and information to meet your needs, and thereby foster increased awareness and involvement in the protection and restoration of our Nation's waters.

The NAWQA Program recognizes that a national assessment by a single program cannot address all water-resource issues of interest. External coordination at all levels is critical for a fully integrated understanding of watersheds and for cost-effective management, regulation, and conservation of our Nation's water resources. The Program, therefore, depends extensively on the advice, cooperation, and information from other Federal, State, interstate, Tribal, and local agencies, non-government organizations, industry, academia, and other stakeholder groups. The assistance and suggestions of all are greatly appreciated.

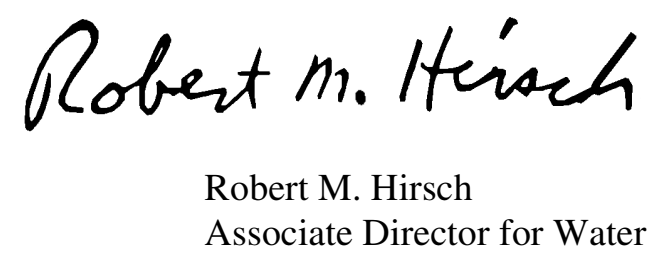





\section{CONTENTS}

Abstract
Introduction .
Purpose and Scope
Description of the Study Area
Water-Temperature Characteristics
Kenai Peninsula
Anchorage Area
Susitna River Basin

\section{FIGURES}

Figure 1. Map showing location of water-temperature and climate sites in the Cook Inlet Basin, Alaska .........................3

Figure 2. Graph showing comparison of discharge between a glacial and a nonglacial stream ......................................5

Figure 3 Graph showing beginning and ending year of available data for water-temperature-measurement sites ..............8

Figure 4. Graph showing average daily maximum and minimum water temperatures for six sites on the

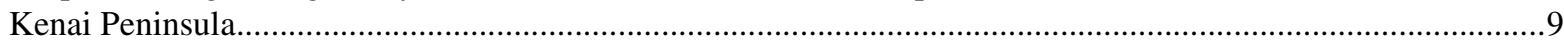

Figure 5. Graph showing average daily maximum and minimum water temperatures for three sites in Anchorage ............9

Figure 6. Graph showing average daily maximum and minimum water temperatures for five sites on the

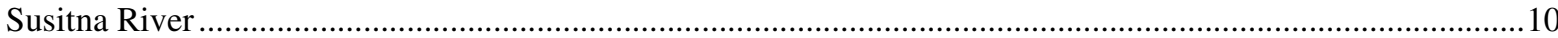

Figure 7. Graph showing average daily maximum and minimum water temperatures for the Chulitna River near Talkeetna, Alaska (site 40)..

Figure 8. Graph showing average daily maximum and minimum water temperatures for the Yentna River near

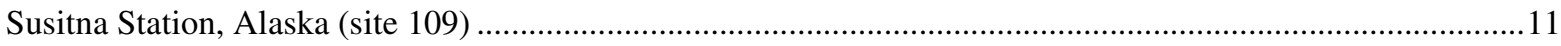

Figure 9. Schematic representation of the logistic function parameters (from Mohseni and others, 1998) ......................12

Figure 10. Graph showing relation of distance between a water-temperature site and its associated air-temperature

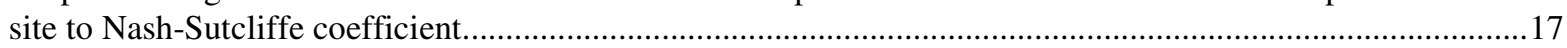

Figure 11. Graph showing relation between percent of watershed covered by glaciers and Nash-Sutcliffe coefficient....... 17

Figure 12. Graph showing relation between weekly average water temperature and weekly average air temperature for Ship Creek below powerplant at Elmendorf Air Force Base at Anchorage, Alaska...................................17

Figure 13. Graph showing relation between weekly average water temperature and weekly average air temperature for Chester Creek at Arctic Boulevard at Anchorage, Alaska .........................................................17

Figure 14. Map showing water-temperature sites in the Cook Inlet Basin with predicted water temperatures greater than 3 degrees Celsius

\section{TABLES}

Table 1. Observed water-temperature ranges for five species of salmon in four freshwater life stages..........................2

Table 2. Water-temperature sites in the Cook Inlet Basin, Alaska ...........................................................................6

Table 3. Climate stations used with water-temperature-regression model ................................................................13

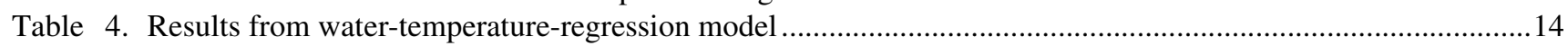

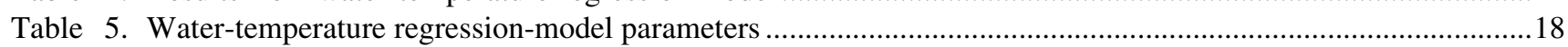

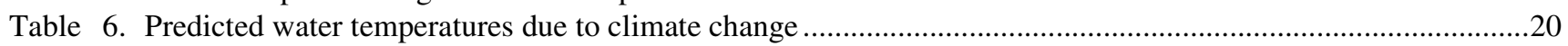




\begin{tabular}{rll}
\hline Multiply & By & To obtain \\
\hline inch (in.) & 25.4 & millimeter $(\mathrm{mm})$ \\
foot $(\mathrm{ft})$ & 0.3048 & meter $(\mathrm{m})$ \\
mile $(\mathrm{mi})$ & 1.609 & kilometer $(\mathrm{km})$ \\
square mile $\left(\mathrm{mi}^{2}\right)$ & 2.590 & square kilometer $\left(\mathrm{km}^{2}\right)$ \\
& & \\
\hline
\end{tabular}

Temperature in degrees Celsius $\left({ }^{\circ} \mathrm{C}\right)$ may be converted to degrees Fahrenheit $\left({ }^{\circ} \mathrm{F}\right)$ as follows:

${ }^{\circ} \mathrm{F}=1.8^{\circ} \mathrm{C}+32$

Sea level: In this report, "sea level" refers to the National Geodetic Vertical Datum of 1929 (NGVD of 1929) — a geodetic datum derived from a general adjustment of the first-order level nets of both the United States and Canada, formerly called Sea Level Datum of 1929.

\section{MAPPING SOURCES:}

Base map modified from U.S. Geological Survey 1:250,000 State base maps.

U.S. Geological Survey Digital Line Graphs published at 1:2,000,000.

Publication projection is Albers Equal Area.

Standard parallels are $55^{\circ} 00^{\prime}$ and $65^{\circ} 00^{\prime}$, central meridian $-154^{\circ} 00^{\prime}$, latitude of projection origin $50^{\circ} 00$. 


\title{
Water Temperature of Streams in the Cook Inlet Basin, Alaska, and Implications of Climate Change
}

\author{
By Rebecca E. Kyle and Timothy P. Brabets
}

\begin{abstract}
Water-temperature data from 32 sites in the Cook Inlet Basin, south-central Alaska, indicate various trends that depend on watershed characteristics. Basins with 25 percent or more of their area consisting of glaciers have the coldest water temperatures during the open-water season, midMay to mid-October. Streams and rivers that drain lowlands have the warmest water temperatures. A model that uses air temperature as input to predict water temperature as output was utilized to simulate future trends in water temperature based on increased air temperatures due to climate warming. Based on the Nash-Sutcliffe coefficient, the model produced acceptable results for 27 sites. For basins with more than 25 percent glacial coverage, the model was not as accurate. Results indicate that 15 sites had a predicted water-temperature change of 3 degrees Celsius or more, a magnitude of change that is considered significant for the incidence of disease in fish populations.
\end{abstract}

\section{INTRODUCTION}

Water temperature is one of the most significant factors in the health of a stream ecosystem (Ward, 1963). Depending on the type of stream and its location, the natural flora and fauna often establish themselves in ranges delineated by temperature. The study of water temperature has many immediate practical applications, such as determining the environmental impacts due to anthropogenic sources (Smith, 1972) and the health of stream biota (Peterson and others, 1977; Alderice and Velsen, 1978; Edwards and others, 1979; Baltz and others, 1987; Eaton and Scheller,
1996; Scheller and others, 1999). Stream temperature can have detrimental effects on various species populations by influencing physical, chemical, and biological water properties (Smith, 1972). For example, if stream temperatures are low (between $4^{\circ} \mathrm{C}$ and $0^{\circ} \mathrm{C}$ ), fish growth slows (Edwards and others, 1979). If temperatures are significantly lower than typical seasonal temperatures, fish egg development may be stunted (Alderice and Velsen, 1978). In contrast, a stream-temperature rise could be unfavorable for a certain species of fish if it encourages predators, disease, or competitors or exceeds the threshold of tolerance. For example, fish will leave a stream reach that becomes increasingly warm (Smith, 1972; Eaton and Scheller, 1996). Biochemical activity increases with warmer water temperatures, which in turn increases the demand for oxygen. Warm water with low dissolved oxygen may create an oxygendeprived environment.

Stream temperature is an important physical factor of Pacific salmon habitat, and its effects on various salmon life stages have been extensively researched (Bell, 1973; Alderice and Velsen, 1978; Murray and McPhail, 1988; Groot and Margolis, 1991). To maximize survival, each species of Pacific salmon has adapted to specific spawning times and temperatures in order that incubation and emergence occur at the most favorable time of the year (table 1). Chum salmon (Oncorhynchus keta) have been observed at temperatures above $20^{\circ} \mathrm{C}$. The U.S. Environmental Protection Agency (1976) water-quality criteria for coho salmon (Oncorhynchus kisutch) assert a maximum weekly mean temperature of $18^{\circ} \mathrm{C}$ for growth and $24^{\circ} \mathrm{C}$ for survival. The physiologically optimum water temperature for salmon depends on the species, the life stage, and the season (Carmen Olito, Alaska Department of Fish and Game, written commun., 2000). 
Table 1. Observed water-temperature ranges for five species of salmon in four freshwater life stages [Data from R\&M Consultants Inc., 1981; values in degrees Celsius]

\begin{tabular}{llcccc}
\hline Species & Migration & Spawning & Incubation & Rearing & $\begin{array}{c}\text { Total range for } \\
\text { all life stages }\end{array}$ \\
\hline Coho & $2.0-15.6$ & $2.0-17.0$ & $1.3-14.0$ & $4.1-5.7$ & $1.3-17.0$ \\
Pink & $4.0-15.6$ & $7.0-18.4$ & $0.5-15.0$ & $4.4-15.7$ & $0.5-18.4$ \\
Chum & $1.5-21.0$ & $1.8-16.0$ & $0.0-15.0$ & $1.3-16.2$ & $0.0-21.0$ \\
Sockeye & $2.5-17.8$ & $4.9-13.0$ & $2.0-14.3$ & $4.4-15.7$ & $2.0-17.8$ \\
Chinook & $4.0-16.0$ & $5.6-13.9$ & $1.5-16.0$ & $4.4-15.7$ & $1.5-16.0$ \\
\end{tabular}

Carpenter and others (1992) noted that one of the initial effects of climate warming would be changes in recreational and commercial fisheries. Because fish are cold-blooded animals, their metabolic rates rise with increasing water temperature. As natural or artificial events shift temperatures away from optimal ranges for fish species, their populations are affected. Fish will actively seek habitats in their preferred temperature range. However, these temperature preferences would still be near the warm side of the fish's fatal temperature limits (Regier and others, 1996). Fish living in freshwater at the mid- to high latitudes are predicted to be the most affected by increased warming at the poles (Rombough, 1996). These temperature changes may stress some fish populations.

Cold-water fish usually cease to grow at temperatures above $20^{\circ} \mathrm{C}$ because of their increased metabolic rate. Carpenter and others (1992) noted that all phases of fish life histories will quicken due to environmental warming. Stream temperature can trigger important physiological and behavioral changes in fish life cycles. Temperature increases may affect the process of transition from freshwater to saltwater (smolting) in juvenile salmonids as well (McCormick and others, 1996). Adult cold-water fish species may cease to migrate or die unspawned if exposed to long periods of warmer than usual temperatures (Bell, 1973). Cold-water fishes are more sensitive to temperature fluctuations during the early stages of their life than as juveniles or adults (Rombough, 1996). Chatters and others (1991) noted that the survival of adult chinook salmon is usually reduced in warmer water.

Cool- and warm-water fish will benefit from warmer waters by the northern expansion of their geographical limit because some of these species do not feed when the water temperature reaches a critical minimum level, so their northern distribution is limited by their physiological ability to survive winter starvation (Shuter and Post, 1990). Conversely, warmer water and increased metabolism will lead to fish population declines if there is an insufficient food source (Carpenter and others, 1992). It is generally agreed that the fish populations most affected by global warming will be cold-water fishes living in habitats near the southern limits of their range. Crawshaw and O'Connor (1997) concluded that increased stream temperatures generally reduce the survival of adult salmon by fostering disease. Chatters and others (1991) stated that a temperature change of $3^{\circ} \mathrm{C}$ or less would have little effect on the incidence of disease, but changes in fish quantity and well-being are expected for temperature changes over $3^{\circ} \mathrm{C}$.

Five species of Pacific salmon use many of the streams and rivers in the Cook Inlet Basin (fig. 1, table 1) for spawning and rearing; continued global warming may alter their spawning and rearing habitat. These salmon populations are of considerable economic significance to area communities. In 1997, the Cook Inlet area accounted for 50 percent of the State's sportfishing angler-days (an angler-day is equivalent to 12 hours of fishing by one person or a combination of persons). The Kenai River, considered Alaska's most popular sportfishing river, sustains one of the State's most valuable salmon fisheries. In 1997, the Kenai River accounted for 12 percent of the angler-days statewide (Howe and others, 1998).

\section{Purpose and Scope}

This study is part of the Cook Inlet Basin National Water-Quality Assessment (NAWQA) Program. The U.S. Geological Survey (USGS) 


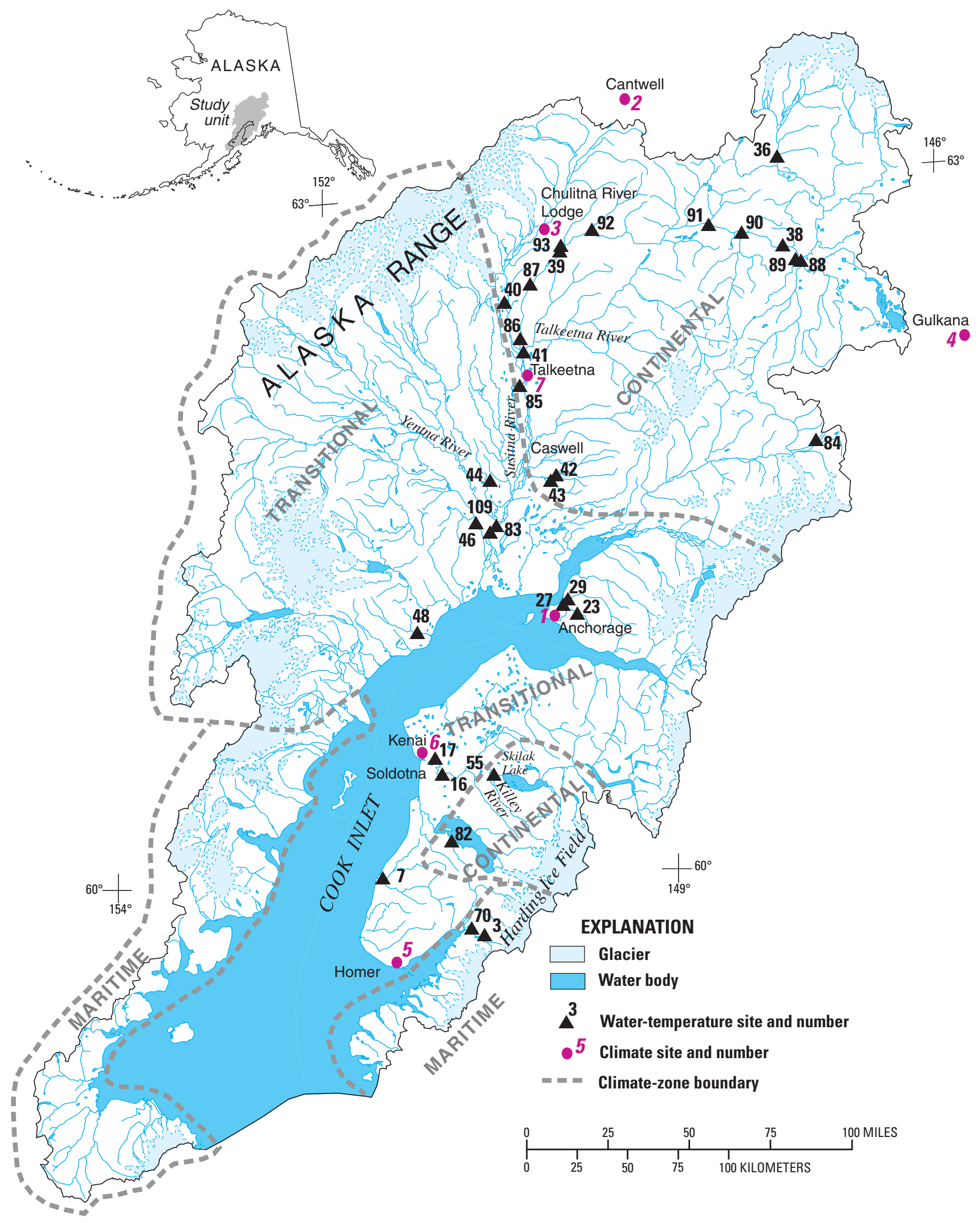

Figure 1. Location of water-temperature and climate sites in the Cook Inlet Basin, Alaska. 
implemented the NAWQA program in 1991, and work in the Cook Inlet Basin Study Unit began in 1997. The purpose of the Cook Inlet Basin NAWQA study is twofold: (1) describe the status and trends in the quality of water resources in the Cook Inlet Basin and (2) provide an understanding of factors affecting water quality and aquatic ecosystems. Because water temperature is an important factor influencing the quality of aquatic habitats, an investigation describing the present and future patterns of water temperature within the Cook Inlet Basin was conducted.

This report (1) compiles all available watertemperature data that have been collected in the Cook Inlet Basin, (2) analyzes those data to determine differences between individual streams and rivers,

(3) tests the accuracy of a water-temperature model, (4) uses the model to simulate future trends in water temperature, and (5) describes how predicted future trends might affect fish habitat. The scope of this study is limited to the Cook Inlet Basin, Alaska.

\section{Methods of Study}

Some of the variables that influence water temperature are solar radiation, air temperature, the source of water input to a stream (such as snowmelt or glacier ice melt), and vegetative cover. The methods used in this study were (1) compilation and analysis of watertemperature data from streams located in the Cook Inlet Basin, (2) compilation of basin characteristics (such as percent glacier for watersheds with streamtemperature data), (3) compilation of air-temperature data from selected climatological stations within the Cook Inlet Basin, (4) calibration and verification of a water-temperature model, and (5) utilization of the water-temperature model with climate-change scenarios for Alaska.

\section{DESCRIPTION OF THE STUDY AREA}

The following description of the Cook Inlet Basin is taken from Brabets and others (1999) and Glass (1999). The Cook Inlet Basin covers 39,325 mi (square miles). Altitude ranges from sea level to the highest point in North America, Mount McKinley, at 20,320 ft (feet). Because of its large size and range in altitude, the Cook Inlet Basin has three climate zones: the Continental, Transition, and Maritime Zones (fig. 1). The Continental Zone has greater temperature highs and lows than the other climate zones and is characterized by an average annual temperature of $-5.5^{\circ} \mathrm{C}$ and an average annual precipitation of about 20 inches. The average annual temperature in the Transitional Zone is about $-5^{\circ} \mathrm{C}$ and average annual precipitation is about 30 inches. The Maritime Zone is the wettest of the three zones, with an average annual temperature of about $8.3^{\circ} \mathrm{C}$ and an average annual precipitation of about 70 inches (Hartman and Johnson, 1978). Evaporation in the Cook Inlet Basin is minimized by the relatively cool climate, high humidity, and cloud cover that predominate over the Cook Inlet Basin. Average annual precipitation for the entire Cook Inlet Basin is about 44 inches, and precipitation in the basin ranges from 20 to 240 inches annually. High mountainous areas (which account for 58 percent of the Cook Inlet land area) receive the greatest amount of precipitation; conversely, the lowland areas receive the least. From November to March, precipitation generally falls as snow. In extremely high mountains, snow is deposited year-round on glaciers and ice fields.

Glaciers cover approximately 11 percent $(4,200$ $\mathrm{mi}^{2}$ ) of the land area of Cook Inlet Basin. Most glaciers are located on the Alaska Range, Harding Ice Field, and western Cook Inlet (fig. 1). Year-round basal ice temperatures near $0^{\circ} \mathrm{C}$ classify glaciers in the basin as temperate. These glaciers store massive amounts of water as ice, and the amount of glacial melt is dependent on the extent of warm meteorological conditions. Streams that have as little as 5 percent glacial ice within their basin have distinct characteristics compared to stream basins with no glaciers. The most disparate feature is mean daily discharge. For example, in a comparison of a basin with glaciers (Susitna River near Denali) and a basin without glaciers (Ninilchik River at Ninilchik), both glacial and nonglacial streams have low stream discharge through the winter because of ice formation, unless ground-water recharge occurs (fig. 2). In April or May, rapid warming triggers ice breakup and snowmelt that increases streamflow. During the warm and dry summer period, the discharge of nonglacial streams declines while the flow of glacier-fed streams remains high due to the continuous melting of snow and ice upstream. 


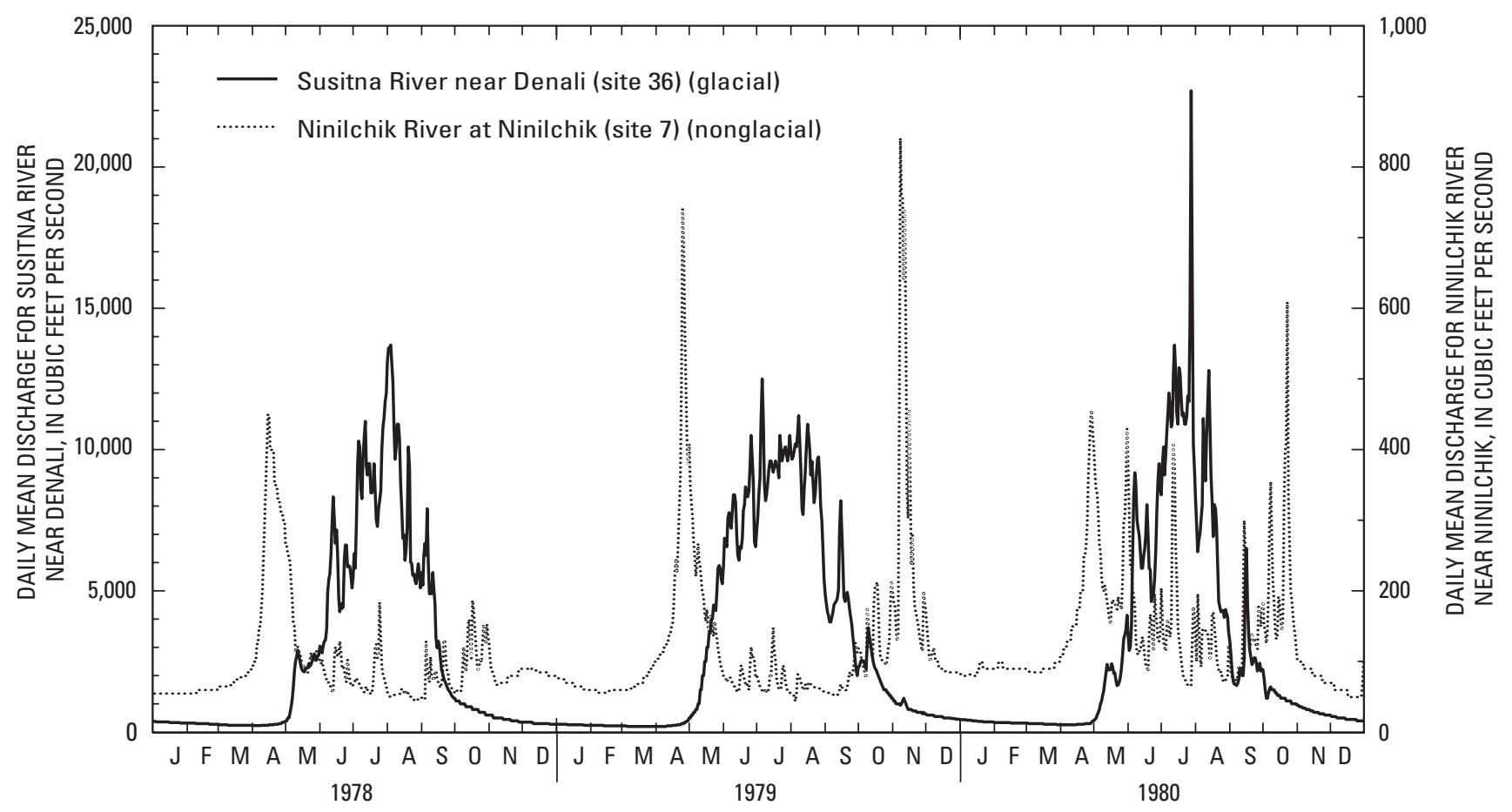

Figure 2. Comparison of discharge between a glacial and a nonglacial stream.

Although glaciers delay the decline of high seasonal flows, the unit discharge for streams in basins with glacial ice coverage is generally larger than for streams in basins without glacial ice.

\section{WATER-TEMPERATURE CHARACTERISTICS}

Water-temperature data, specifically longterm data, for the Cook Inlet Basin are sparse. Many measurement sites are concentrated in one area and may not represent all the different types of streams and rivers in the basin. As water-temperature data were examined, it was common to find records with few complete weekly water-temperature measurements. Streams draining into west Cook Inlet are underrepresented. Ice formation affected the quality of observed data. In their study on changes in thermal habitat of Great Lakes fish due to global warming, Magnuson and others (1990) noted that the validity of their results lies in the quality of their data and the structure of their models. Thus, the importance of quality and quantity of baseline data cannot be overemphasized, and conclusions resulting from this study should be reevaluated as more data is collected in this region.
Water-temperature information for 32 sites in the Cook Inlet Basin (fig. 1, table 2) were obtained from the Alaska Power Authority (APA) studies for the Susitna River Hydroelectric Project (R\&M Consultants, Inc., 1981), the Alaska Department of Fish and Game (ADFG) (1983, 1984), and the U.S. Geological Survey National Water Information System (NWIS). Data from all sources were collected from 1969 through 2000, although the period of record varied from stream to stream (fig. 3). The shortest records extended 2 years and the longest period of record was 7 years for site 27 . Due to the difficulty of collecting water-temperature data during winter, most sites have water-temperature data only for the open-water period, which is generally from mid-May to mid-October (table 2).

The distribution of sites with water-temperature data is not uniform (fig. 1). As a result of environmental studies conducted for proposed hydropower facilities in the early 1980's, there are 20 sites in the Susitna Basin, the largest number of sites in any of the basins of Cook Inlet. Water-temperature data collected at other sites include the Anchorage urban area ( 3 sites) and the Kenai Peninsula ( 7 sites). Based on the data from these sites, general observations can be made about the water-temperature characteristics of these three areas. 
Table 2. Water-temperature sites in the Cook Inlet Basin, Alaska

[USGS, U.S. Geological Survey; ft, feet; AK, Alaska; ADF\&G, Alaska Department of Fish and Game; APA, Alaska Power Authority; --- drainage area not determined; E, estimated]

\begin{tabular}{|c|c|c|c|c|c|c|c|c|}
\hline $\begin{array}{c}\text { Map } \\
\text { number } \\
\text { (figure 1) }\end{array}$ & $\begin{array}{l}\text { USGS station } \\
\text { number or } \\
\text { latitude/longitude }\end{array}$ & Station name & $\begin{array}{l}\text { Elevation } \\
\quad(\mathrm{ft})\end{array}$ & $\begin{array}{l}\text { Data } \\
\text { source }\end{array}$ & $\begin{array}{l}\text { Period } \\
\text { of record }\end{array}$ & $\begin{array}{l}\text { Drainage area } \\
\text { (square miles) }\end{array}$ & $\begin{array}{l}\text { Percent } \\
\text { glaciers }\end{array}$ & Climate zone \\
\hline 3 & 15239000 & $\begin{array}{l}\text { Bradley River near } \\
\text { Homer, AK }\end{array}$ & 1,054 & USGS & $\begin{array}{l}1979-86 \\
\text { seasonal }\end{array}$ & 54 & 36 & Maritime \\
\hline 70 & 15239070 & $\begin{array}{l}\text { Bradley River near tide- } \\
\text { water near Homer, AK }\end{array}$ & 25 & USGS & $\begin{array}{l}\text { 1986-99 } \\
\text { yearly }\end{array}$ & --- & --- & Maritime \\
\hline 7 & 15241600 & $\begin{array}{l}\text { Ninilchik River at } \\
\text { Ninilchik, AK }\end{array}$ & 30 & USGS & $\begin{array}{l}1998 \\
\text { yearly }\end{array}$ & 131 & 0 & Transitional \\
\hline 82 & $\begin{array}{l}60^{\circ} 11^{\prime} 00^{\prime \prime} \\
151^{\circ} 00^{\prime} 00^{\prime \prime}\end{array}$ & $\begin{array}{l}\text { Nikolai Creek near } \\
\text { Kasilof, AK }\end{array}$ & 180 & USGS & $\begin{array}{l}1990-92 \\
\text { seasonal }\end{array}$ & --- & 0 & Continental \\
\hline 55 & 15266110 & $\begin{array}{l}\text { Kenai River below } \\
\text { Skilak Lake outlet } \\
\text { near Sterling, AK }\end{array}$ & 240 & USGS & $\begin{array}{l}1998 \\
\text { yearly }\end{array}$ & 1,206 & 14 & Continental \\
\hline 16 & 15266300 & $\begin{array}{l}\text { Kenai River at } \\
\text { Soldotna, AK }\end{array}$ & 35 & USGS & $\begin{array}{l}1998 \\
\text { yearly }\end{array}$ & 1,951 & 10 & Transitional \\
\hline 17 & 15266500 & $\begin{array}{l}\text { Beaver Creek near } \\
\text { Kenai, AK }\end{array}$ & 48 & USGS & $\begin{array}{l}1969-75 \\
\text { yearly }\end{array}$ & 51 & 0 & Transitional \\
\hline 48 & 15294450 & $\begin{array}{l}\text { Chuitna River near } \\
\text { Tyonek, AK }\end{array}$ & 160 & USGS & $\begin{array}{l}1976-78 \\
\text { seasonal }\end{array}$ & 131 & 0 & Transitional \\
\hline 23 & 15274000 & $\begin{array}{l}\text { South Fork Campbell Creek } \\
\text { near Anchorage, AK }\end{array}$ & 260 & USGS & $\begin{array}{l}1998 \\
\text { yearly }\end{array}$ & 29.4 & 0 & Transitional \\
\hline 27 & 15275100 & $\begin{array}{l}\text { Chester Creek at } \\
\text { Arctic Boulevard at } \\
\text { Anchorage, AK }\end{array}$ & 16 & USGS & $\begin{array}{l}1981-86 \\
1998 \\
\text { yearly }\end{array}$ & 27.3 & 0 & Transitional \\
\hline 29 & 15276570 & $\begin{array}{l}\text { Ship Creek below power- } \\
\text { plant at Elmendorf Air Force } \\
\text { Base at Anchorage, AK }\end{array}$ & 80 & USGS & $\begin{array}{l}1971-80 \\
\text { yearly }\end{array}$ & 113 & 0 & Transitional \\
\hline 46 & 15294350 & $\begin{array}{l}\text { Susitna River at Susitna } \\
\text { Station, AK }\end{array}$ & 40 & USGS & $\begin{array}{l}1977-83 \\
\text { seasonal }\end{array}$ & 19,400 & 11 & Transitional \\
\hline 83 & $\begin{array}{l}61^{\circ} 34^{\prime} 00^{\prime \prime} \\
150^{\circ} 25^{\prime} 00^{\prime \prime}\end{array}$ & $\begin{array}{l}\text { Susitna River above } \\
\text { Yentna River near } \\
\text { Susitna Station, AK }\end{array}$ & 40 & $\begin{array}{l}\text { ADF\&G; } \\
\text { APA }\end{array}$ & $\begin{array}{l}1982-83 \\
\text { seasonal }\end{array}$ & E 13,200 & E 10 & Transitional \\
\hline 43 & 15294010 & $\begin{array}{l}\text { Deception Creek near } \\
\text { Willow, AK }\end{array}$ & 250 & USGS & $\begin{array}{l}1978-85 \\
\text { seasonal }\end{array}$ & 48 & 0 & Continental \\
\hline 42 & 15294005 & $\begin{array}{l}\text { Willow Creek near } \\
\text { Willow, AK }\end{array}$ & 350 & USGS & $\begin{array}{l}\text { 1979-86 } \\
\text { seasonal }\end{array}$ & 166 & 0 & Continental \\
\hline 44 & 15294100 & $\begin{array}{l}\text { Deshka River near } \\
\text { Willow, AK }\end{array}$ & 80 & USGS & $\begin{array}{l}1999 \\
\text { yearly }\end{array}$ & 591 & 0 & Transitional \\
\hline
\end{tabular}


Table 2. Water-temperature sites in the Cook Inlet Basin, Alaska-Continued

[USGS, U.S. Geological Survey; ft, feet; AK, Alaska; ADF\&G, Alaska Department of Fish and Game; APA, Alaska Power Authority; --- drainage area not determined; E, estimated]

\begin{tabular}{|c|c|c|c|c|c|c|c|c|}
\hline $\begin{array}{c}\text { Map } \\
\text { number } \\
\text { (figure 1) }\end{array}$ & $\begin{array}{c}\text { USGS station } \\
\text { number or } \\
\text { latitude/longitude }\end{array}$ & Station name & $\begin{array}{l}\text { Elevation } \\
\text { (ft) }\end{array}$ & $\begin{array}{l}\text { Data } \\
\text { source }\end{array}$ & $\begin{array}{l}\text { Period } \\
\text { of record }^{2}\end{array}$ & $\begin{array}{r}\text { Drainage area } \\
\text { (square miles) }\end{array}$ & $\begin{array}{l}\text { Percent } \\
\text { glaciers }\end{array}$ & Climate zone \\
\hline 84 & 15281500 & $\begin{array}{l}\text { Camp Creek near Sheep } \\
\text { Mountain Lodge, AK }\end{array}$ & 2,950 & USGS & $\begin{array}{l}1996 \\
\text { seasonal }\end{array}$ & 1.09 & 0 & Continental \\
\hline 85 & 15292780 & $\begin{array}{l}\text { Susitna River at } \\
\text { Sunshine, AK }\end{array}$ & 300 & $\begin{array}{l}\text { ADF\&G; } \\
\text { APA }\end{array}$ & $\begin{array}{l}1982-83 \\
\text { seasonal }\end{array}$ & 11,100 & 10 & Continental \\
\hline 41 & 15292700 & $\begin{array}{l}\text { Talkeetna River near } \\
\text { Talkeetna, AK }\end{array}$ & 400 & $\begin{array}{l}\text { ADF\&G; } \\
\text { APA }\end{array}$ & $\begin{array}{l}1982-83 \\
\text { seasonal }\end{array}$ & 1,996 & 7 & Continental \\
\hline 86 & $\begin{array}{l}62^{\circ} 23^{\prime} 00^{\prime \prime} \\
150^{\circ} 08^{\prime} 00^{\prime \prime}\end{array}$ & $\begin{array}{l}\text { Susitna River near } \\
\text { Talkeetna, AK }\end{array}$ & 400 & $\begin{array}{l}\text { ADF\&G; } \\
\text { APA }\end{array}$ & $\begin{array}{l}1982-83 \\
\text { seasonal }\end{array}$ & E 6,534 & E 5 & Continental \\
\hline 40 & 15292400 & $\begin{array}{l}\text { Chulitna River near } \\
\text { Talkeetna, AK }\end{array}$ & 500 & USGS & $\begin{array}{l}1982-86 \\
\text { seasonal }\end{array}$ & 2,570 & 27 & Continental \\
\hline 87 & $\begin{array}{l}62^{\circ} 37^{\prime} 00^{\prime \prime} \\
150^{\circ} 00^{\prime} 00^{\prime \prime}\end{array}$ & $\begin{array}{l}\text { Susitna River at } \\
\text { Curry, AK }\end{array}$ & 550 & $\begin{array}{l}\text { ADF\&G; } \\
\text { APA }\end{array}$ & $\begin{array}{l}1982-83 \\
\text { seasonal }\end{array}$ & E 6,534 & E 5 & Continental \\
\hline 88 & $\begin{array}{l}62^{\circ} 38^{\prime} 00^{\prime \prime} \\
147^{\circ} 22^{\prime} 00^{\prime \prime}\end{array}$ & $\begin{array}{l}\text { Oshetna River near } \\
\text { Cantwell, AK }\end{array}$ & 2,100 & $\begin{array}{l}\text { ADF\&G; } \\
\text { APA }\end{array}$ & $\begin{array}{l}1982-83 \\
\text { seasonal }\end{array}$ & --- & 0 & Continental \\
\hline 89 & $\begin{array}{l}62^{\circ} 38^{\prime} 00^{\prime \prime} \\
147^{\circ} 26^{\prime} 00^{\prime \prime}\end{array}$ & $\begin{array}{l}\text { Goose Creek near } \\
\text { Cantwell, AK }\end{array}$ & 2,100 & $\begin{array}{l}\text { ADF \&G; } \\
\text { APA }\end{array}$ & $\begin{array}{l}\text { 1982-83 } \\
\text { seasonal }\end{array}$ & --- & 0 & Continental \\
\hline 38 & 15291500 & $\begin{array}{l}\text { Susitna River near } \\
\text { Cantwell, AK }\end{array}$ & 1,900 & USGS & $\begin{array}{l}1971-74 \\
1980-86 \\
\text { seasonal }\end{array}$ & 4,140 & 7 & Continental \\
\hline 39 & 15292000 & $\begin{array}{l}\text { Susitna River at } \\
\text { Gold Creek, AK }\end{array}$ & 678 & USGS & $\begin{array}{l}1974-75 \\
1977-85 \\
\text { seasonal }\end{array}$ & 6,160 & 5 & Continental \\
\hline 90 & $\begin{array}{l}62^{\circ} 46^{\prime} 00^{\prime \prime} \\
147^{\circ} 56^{\prime} 00^{\prime \prime}\end{array}$ & $\begin{array}{l}\text { Kosina Creek near } \\
\text { Cantwell, AK }\end{array}$ & 1,600 & $\begin{array}{l}\text { ADF\&G; } \\
\text { APA }\end{array}$ & $\begin{array}{l}1982-83 \\
\text { seasonal }\end{array}$ & --- & 0 & Continental \\
\hline 93 & $\begin{array}{l}62^{\circ} 47^{\prime} 18^{\prime \prime} \\
149^{\circ} 39^{\prime} 36^{\prime \prime}\end{array}$ & $\begin{array}{l}\text { Indian River near } \\
\text { Gold Creek, AK }\end{array}$ & 750 & $\begin{array}{l}\text { ADF \&G; } \\
\text { APA }\end{array}$ & $\begin{array}{l}1982-83 \\
\text { seasonal }\end{array}$ & --- & 0 & Continental \\
\hline 91 & $\begin{array}{l}62^{\circ} 49^{\prime} 00^{\prime \prime} \\
148^{\circ} 15^{\prime} 00^{\prime \prime}\end{array}$ & $\begin{array}{l}\text { Watana Creek near } \\
\text { Cantwell, AK }\end{array}$ & 1,500 & $\begin{array}{l}\text { ADF\&G; } \\
\text { APA }\end{array}$ & $\begin{array}{l}1982-83 \\
\text { seasonal }\end{array}$ & --- & 0 & Continental \\
\hline 92 & $\begin{array}{l}62^{\circ} 50^{\prime} 00^{\prime \prime} \\
149^{\circ} 22^{\prime} 35^{\prime \prime}\end{array}$ & $\begin{array}{l}\text { Portage Creek near } \\
\text { Gold Creek, AK }\end{array}$ & 900 & $\begin{array}{l}\text { ADF \&G; } \\
\text { APA }\end{array}$ & $\begin{array}{l}1982-83 \\
\text { seasonal }\end{array}$ & --- & 0 & Continental \\
\hline 36 & 15291000 & $\begin{array}{l}\text { Susitna River near } \\
\text { Denali, AK }\end{array}$ & 2,440 & USGS & $\begin{array}{l}1974-82 \\
\text { seasonal }\end{array}$ & 950 & 25 & Continental \\
\hline 109 & 15294345 & $\begin{array}{l}\text { Yentna River near } \\
\text { Susitna Station, AK }\end{array}$ & 80 & USGS & $\begin{array}{l}1981-86 \\
\text { seasonal }\end{array}$ & 6,180 & 15 & Transitional \\
\hline
\end{tabular}

${ }^{1}$ The Cook Inlet NAWQA study unit established a uniform numbering system for all surface water sites located in the study basin

For a complete list of stations and numbers see http://ak.water.usgs.gov/Projects/Nawqa.

${ }^{2}$ Data from sites operated seasonally span the open-water period, generally mid-May to mid-October. 


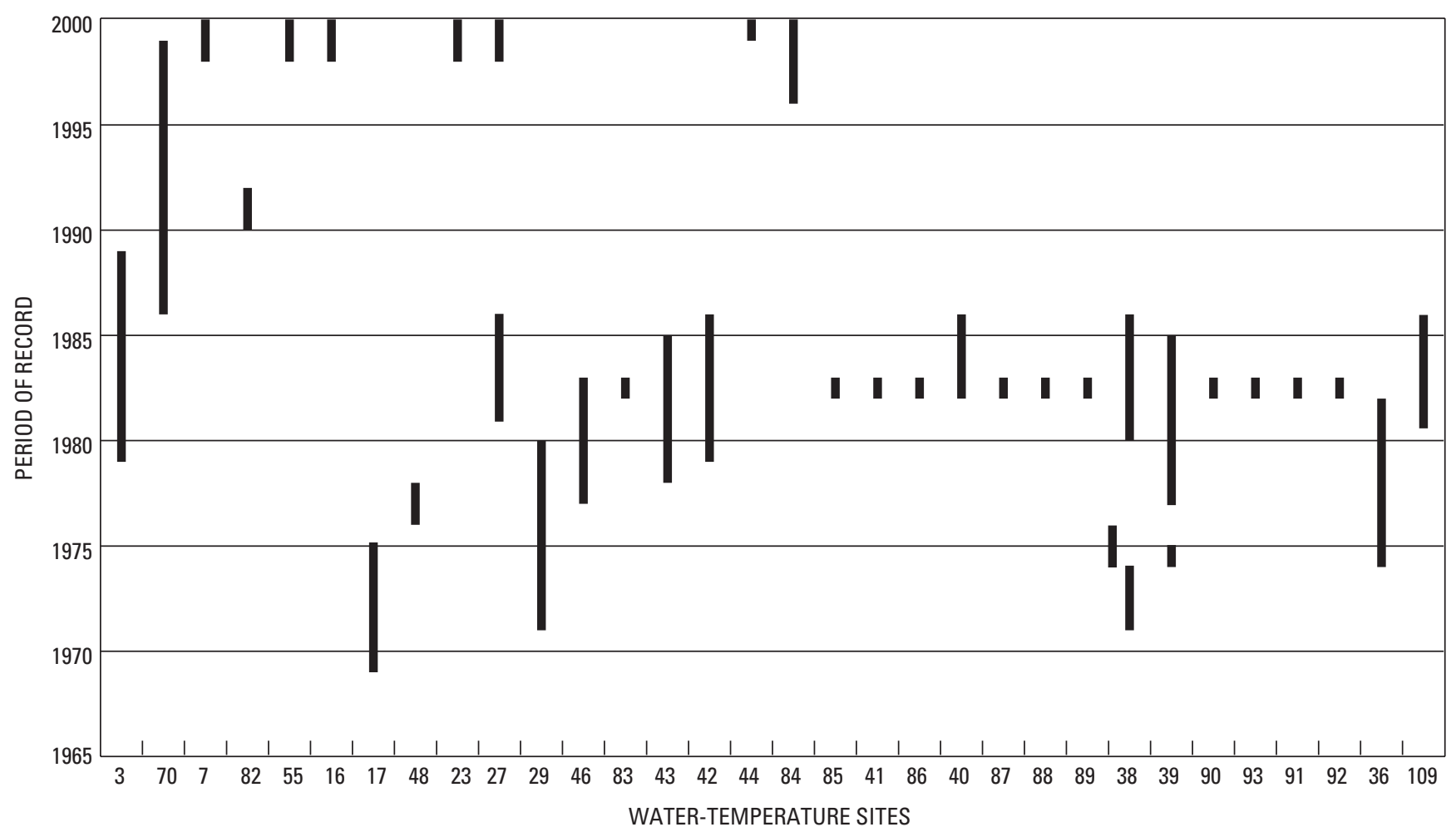

Figure 3. Beginning and ending year of available data for water-temperature-measurement sites.

\section{Kenai Peninsula}

Water-temperature-measurement sites in the Kenai Peninsula are located in all three climate zones-Maritime, Transitional, and Continental (fig. 1). Sites on the Bradley River are located in the Maritime Zone and reflect the influence of glaciers. Site 3 on the Bradley River monitors a basin with 36 percent of its area consisting of glaciers. Inflow of glacial meltwater throughout July and August maintains the water temperature between $4^{\circ} \mathrm{C}$ and $9^{\circ} \mathrm{C}$ (fig. 4). Farther downstream, the effects from additional water from tributary basins with no glaciers have a general warming effect on the river, as indicated by the data at site 70 . Water temperature at this site ranges from about $5^{\circ} \mathrm{C}$ to $11^{\circ} \mathrm{C}$ during July and August.

Beaver Creek (site 17) and the Ninilchik River (site 7) (fig. 4) represent streams in lowland areas. Water temperatures in these streams remain at $0^{\circ} \mathrm{C}$ throughout the winter. During and after snowmelt, water temperature rises throughout early to midsummer and begins to cool in late summer. Fluctuations in water temperature are most likely linked with air temperature or rainfall.

Water-temperature data are available for two sites on the Kenai River. Site 55 is located downstream from the outlet of Skilak Lake. Skilak Lake has a somewhat moderating effect on the water temperature (fig. 4). Water temperature gradually falls to $0^{\circ} \mathrm{C}$ from October to January. Water temperatures at the downstream site, Kenai River at Soldotna (site 16), are slightly lower than at the upstream site and are probably affected by inflow from the Killey River, a glacierized watershed located between the two sites.

\section{Anchorage Area}

Water-temperature data are available for three streams in the Anchorage area, each of which drains an area having a different land use. South Fork Campbell Creek (site 23) drains primarily an undisturbed, high elevation watershed. Chester Creek (site 27) drains an urbanized, residential watershed. Both of these basins are approximately $30 \mathrm{mi}^{2}$ in area. Water-temperature data for Ship Creek, which drains a $113 \mathrm{mi}^{2}$ watershed, is collected downstream from the outfall of a powerplant.

South Fork Campbell Creek is the coldest of the three streams (fig. 5). Most of the flow at this site is either runoff from the upper mountains in the basin or ground water. Chester Creek is the warmest of the three streams during the summer. This may be because of urban development within the basin or because the lower part of the basin drains lowlands. 

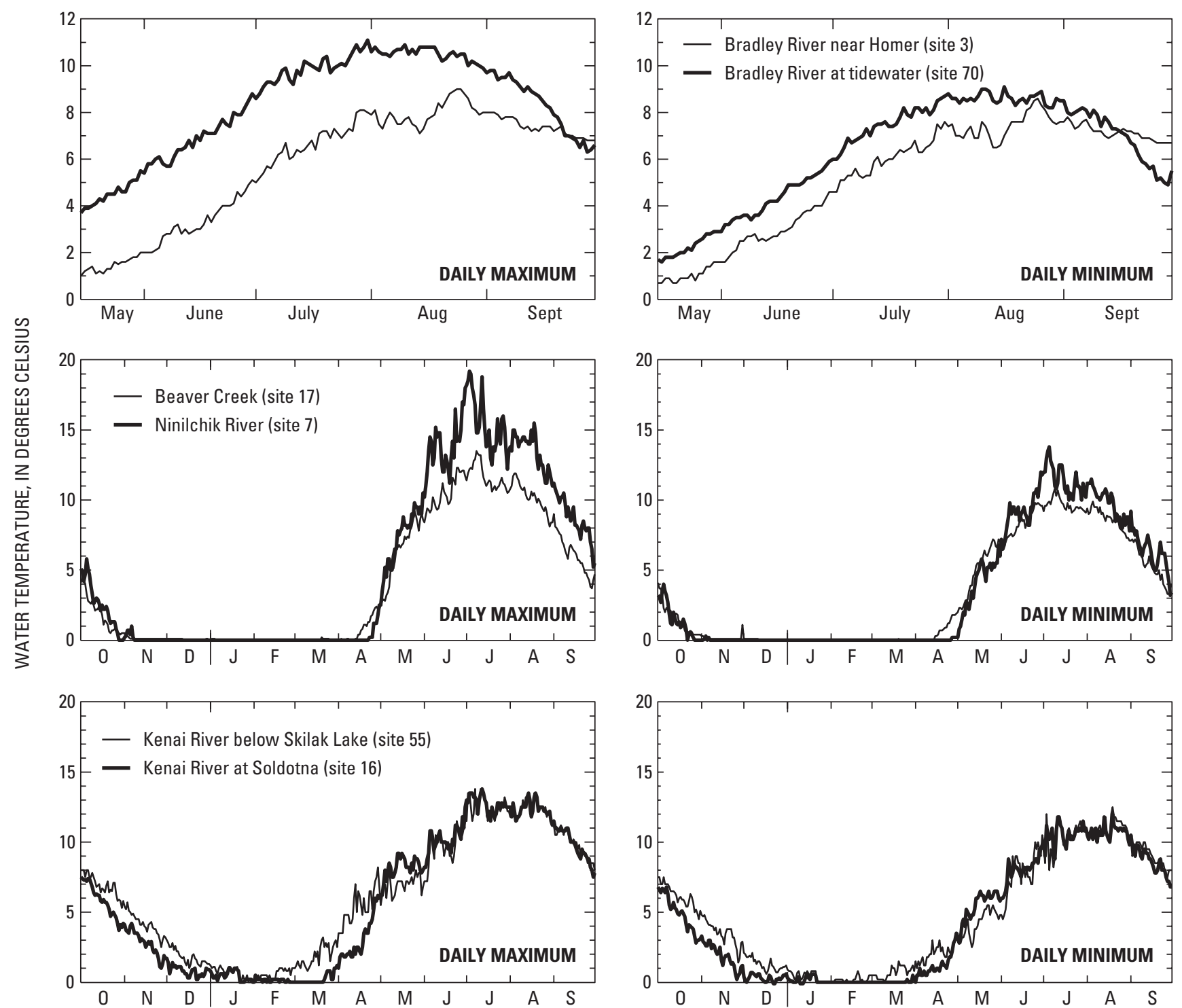

Figure 4. Average daily maximum and minimum water temperatures for six sites on the Kenai Peninsula.
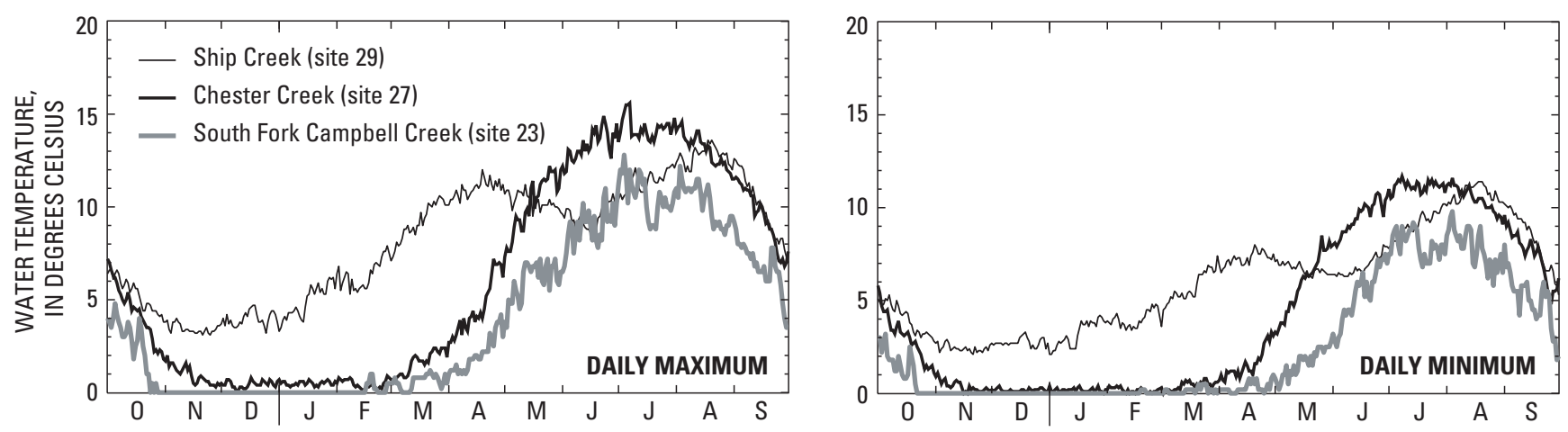

Figure 5. Average daily maximum and minimum water temperatures for three sites in Anchorage. 
At Ship Creek, the outflow from the powerplant has a noticeable effect on water temperature during the winter. Temperatures at this site range from $2^{\circ} \mathrm{C}$ to about $11^{\circ} \mathrm{C}$, while water temperature at Chester Creek and South Fork Campbell Creek remains near $0^{\circ} \mathrm{C}$. During the summer, as additional water enters Ship Creek from snowmelt, effects of outflow from the powerplant on water-temperature decrease.

\section{Susitna River Basin}

The Susitna River Basin encompasses about one-half of the Cook Inlet drainage basin and is the largest watershed in the study area. In the early 1980's, a number of studies took place in the Susitna River Basin as part of an environmental assessment for the proposed Susitna Hydroelectric Project. Thus, watertemperature data are available for many sites in the basin, 20 in all (fig. 1), and provide a good overview of the water-temperature characteristics from the headwaters to the mouth.
Site 36, the Susitna River near Denali, monitors a $950 \mathrm{mi}^{2}$ watershed 25 percent of which consists of glaciers. Glacial meltwater dominates the discharge at this site during the summer runoff period (fig. 2). Daily minimum water temperature ranges from $0.5^{\circ} \mathrm{C}$ to $5.0^{\circ} \mathrm{C}$, (fig. 6) and daily maximum water temperature during the summer ranges from $2^{\circ} \mathrm{C}$ to $8.5^{\circ} \mathrm{C}$. At site 38, the Susitna River near Cantwell, water temperatures are not influenced by glacial meltwater to the same extent as at site 36 . Glaciers comprise 7 percent of the 4,140 $\mathrm{mi}^{2}$ drainage area upstream of the Susitna River near Cantwell site. Flow is dominated by nonglacier-fed streams. Daily minimum water temperatures at this site ranged from about $2^{\circ} \mathrm{C}$ to $11^{\circ} \mathrm{C}$, and daily maximum temperature ranged from $4^{\circ} \mathrm{C}$ to $12.5^{\circ} \mathrm{C}$. Downstream of this site, the Susitna River near Gold Creek site (site 39) monitors drainage from $6,160 \mathrm{mi}^{2}$, of which 5 percent consists of glaciers. At this site there is less influence due to glacier melt than at sites 38 and 36, and water temperatures are generally higher than at the upstream sites throughout the summer.

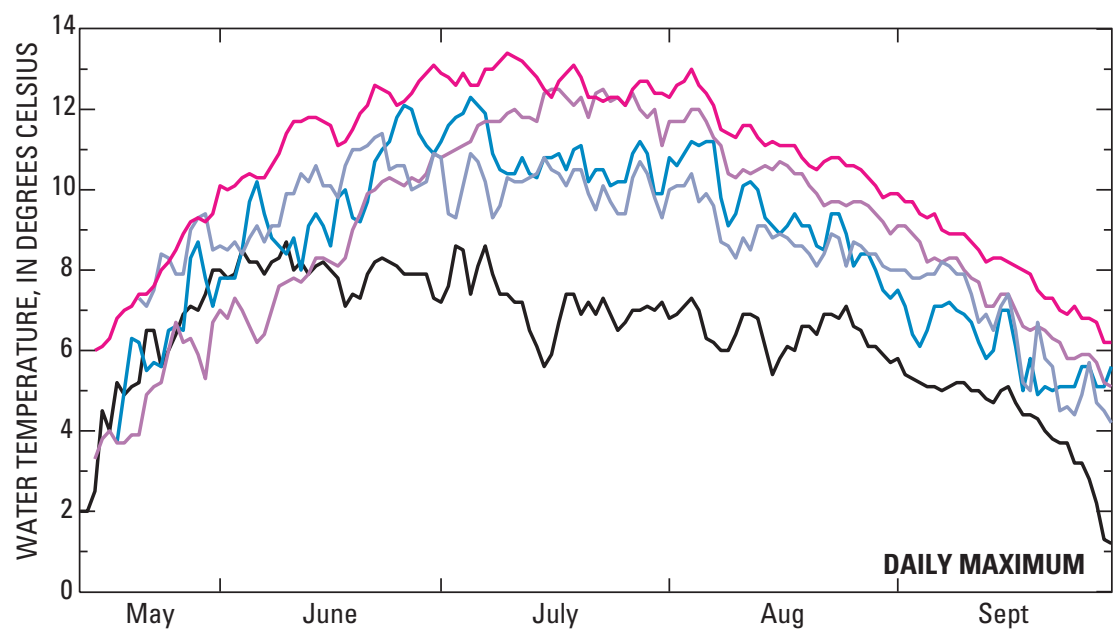

\section{EXPLANATION}

_ Susitna River near Denali (site 36)

_ Susitna River near Cantwell (site 38)

_ Susitna River at Gold Creek (site 39)

Susitna River at Sunshine (site 85)

Susitna River at Susitna Station (site 46)

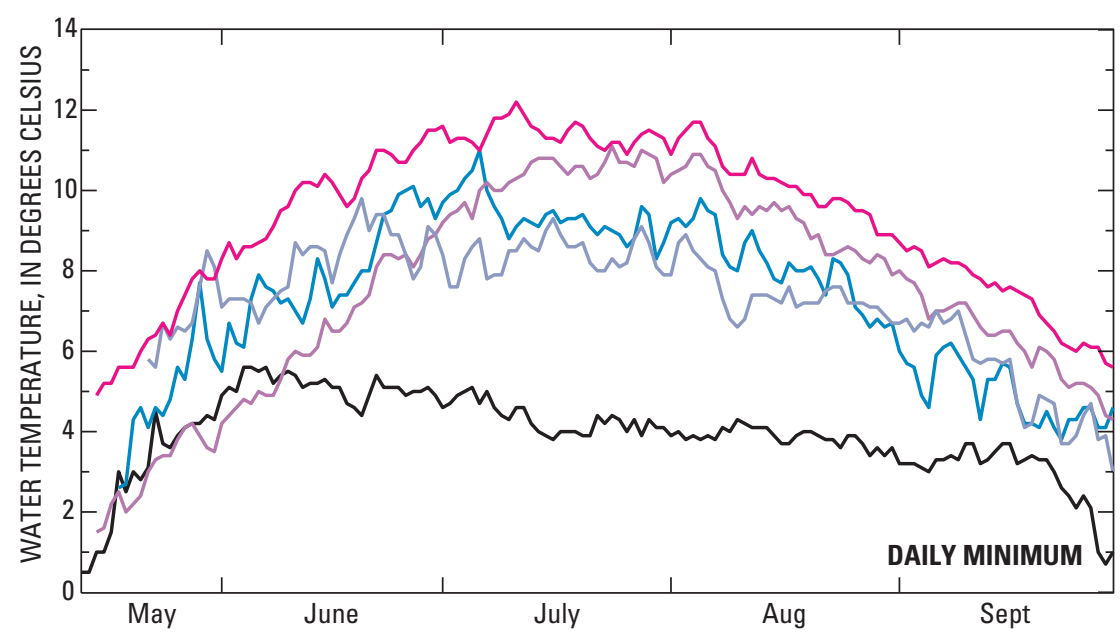

Figure 6. Average daily maximum and minimum water temperatures for five sites on the Susitna River. 
Downstream of the Susitna River near Gold Creek, two major tributaries enter the Susitna River-the Chulitna River and the Talkeetna River. The Chulitna River drains an area of 2,570 $\mathrm{mi}^{2}$ and 27 percent of the watershed consists of glaciers. The Talkeetna River drains an area of $1,996 \mathrm{mi}^{2}$ and 7 percent of the area consists of glaciers. Watertemperature characteristics of the Chulitna River near Talkeetna (site 40) (fig. 7) are quite similar to those at the Susitna River near Denali site (site 36) (fig. 7), reflecting the influence of glacial meltwater. Water temperatures throughout the runoff season are less than $10^{\circ} \mathrm{C}$. The combined effects of the Chulitna and Talkeetna Rivers are noticeable at site 85, the Susitna River at Sunshine (fig. 6). Water temperatures at this site generally are lower than the water temperatures of the Susitna River at Gold Creek (site 39) from July through September, when glacial melt is at its peak.

The last major tributary to the Susitna River downstream of Sunshine is the Yentna River. The Yentna River Basin is $6,180 \mathrm{mi}^{2}, 15$ percent of which consists of glaciers. Water-temperature data do not indicate any significant glacial influence, with daily maximum summer water temperatures ranging from $5^{\circ} \mathrm{C}$ to $12^{\circ} \mathrm{C}$ (fig. 8). Site 46 , the Susitna River at Susitna Station, monitors drainage from 93 percent of the Susitna River Basin. The highest daily maximum water temperatures of the main stem of the Susitna River were recorded at this site and ranged from $5^{\circ} \mathrm{C}$ to $13.5^{\circ} \mathrm{C}$ (fig. 6 ).

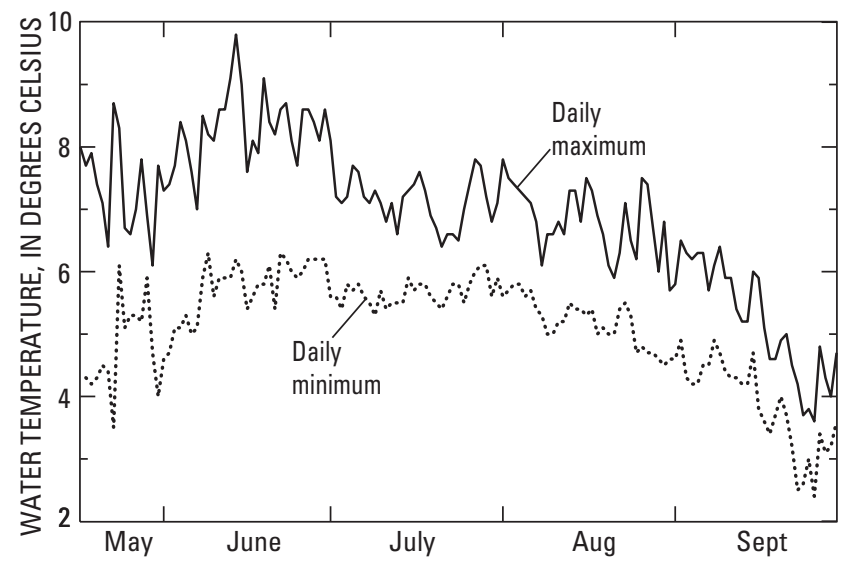

Figure 7. Average daily maximum and minimum water temperatures for the Chulitna River near Talkeetna, Alaska (site 40).

\section{FUTURE TRENDS IN WATER-TEMPERATURE CHARACTERISTICS}

\section{Climate Change}

Alaska has experienced the largest regional warming of any State in the United States, with a rise in average annual temperature of about $3^{\circ} \mathrm{C}$ since the 1960 's and $4.5^{\circ} \mathrm{C}$ in winter (Alaska Regional Assessment Group, 1999). There has been extensive melting of glaciers and thawing of permafrost during this period. Warming also has been associated with an increase in precipitation of about 30 percent between 1968 and 1990 (Alaska Regional Assessment Group, 1999). The Alaskan regional warming is part of a larger warming trend throughout the Arctic.

General Circulation Models (GCMs) have been used to project future climates in Alaska. The two most widely used GCMs are the Canadian Climate Model (CCM) (Canadian Centre for Climate Modeling and Analysis, no date) and the Hadley Center Model (HCM) (Hadley Centre for Climate Prediction and Research, no date). Both GCMs have projected trends toward a warmer and wetter climate. For Cook Inlet, the Canadian model projects the largest warming trends, with an increase in air temperature ranging from $5^{\circ} \mathrm{C}$ to $10^{\circ} \mathrm{C}$ by the year 2100 , whereas the Hadley model projects an increase in air temperature ranging from $4^{\circ} \mathrm{C}$ to $6.5^{\circ} \mathrm{C}$ by 2100 . Precipitation is projected to increase between 20 and 25 percent. Alaska's fisheries can be expected to be affected as the climate continues to warm (Alaska Regional Assessment Group, 1999).

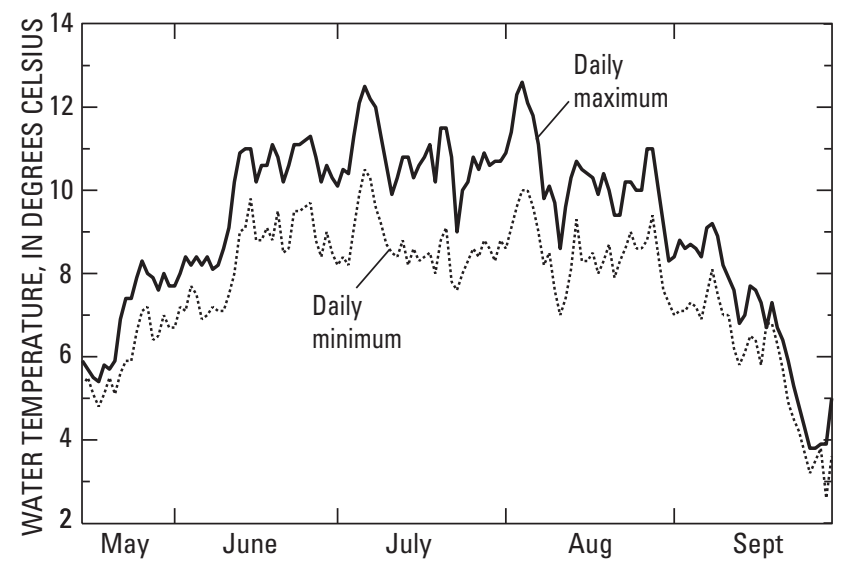

Figure 8. Average daily maximum and minimum water temperatures for the Yentna River near Susitna Station, Alaska (site 109). 


\section{Water-Temperature Model}

Multiple factors influence stream temperature. Climatological factors include air temperature, solar radiation, and precipitation (as both snow and rain); hydrological factors include discharge and channel form; and geological factors include base-flow contributions, such as ground-water seepage and channel form (Smith and Lavis, 1975; Webb and Nobilis, 1997). Physical land-surface characteristics of the basin, including forest cover, glacial influence, aspect, and elevation additionally affect stream temperatures (Johnson, 1971). The most significant environmental factors that influence stream temperature depend on time scale. For example, Mohseni and Stefan (1999) found that in daily time scales, the upstream water temperature has more influence on water temperature than current weather conditions at a certain stream site; therefore, the use of traveltime or lag should be considered. When the time scale is increased to a weekly or annual scale, the air/water temperature equilibrium is more significant and a timelag is not necessary. Eaton and Scheller (1996) noted that a weekly time scale is traditionally and adequately used to assess changes in fish habitat and growth conditions.

In a study done in England, Crisp and Howson (1982) found that a linear regression of mean air temperature with mean stream temperature accounted for 87-95 percent of the variance in water temperatures. Regression equations that included rainfall and discharge made only small improvements, ranging from 5 to 13 percent. In addition, air temperatures from distant stations did not significantly reduce the accuracy of water-temperature models (Crisp and Howson, 1982; Mohseni and others, 1998).

Linear-regression models for stream temperatures are easy to develop, but also have some limitations. At very high and low air temperatures, the water/air temperature relationship does not stay linear. At high temperatures, evaporative cooling allows the water body to lose more heat and stream temperature no longer increases linearly with air temperature. Conversely, a separate function is needed for water temperature when air temperatures dip below freezing (Mohseni and others, 1998). Also, spring stream temperatures are strongly affected by snowmelt and runoff. Autumn temperatures are generally higher than spring temperatures because of the general lack of snow, less streamflow, and, in late autumn, the release of latent heat from ice formation (Webb and Nobilis, 1997).
Studies on the influence of air temperature on water temperature are ongoing and numerous. Many different models of stream temperature have been developed, such as heat advection/dispersion transport models, models based on the concept of equilibrium temperature and processes of surface-heat transfer, seasonal and sinusoidal functions with respect to time, and linear regressions of air and stream temperature (Ward, 1963; Edinger and others, 1966; Brown, 1969; Johnson, 1971; Song and others, 1973; Crisp and Howson, 1982; Sinokrot and Stefan, 1993; Stefan and Preud'homme, 1993; Mohseni and others, 1998; Pilgrim and others, 1998).

Mohseni and others (1998) developed a nonlinear-regression model that uses a logistic function to determine weekly stream temperatures; this model overcame several of the previously mentioned limitations. The model creates an S-shaped graph (fig. 9) that has a more gradual slope at extreme temperatures, which is the typical shape of the logistic function and is represented as follows:

$$
T_{s}=\mu+\frac{\alpha-\mu}{1+e^{\gamma\left(\beta-T_{a}\right)}},
$$

where

$T_{S}$ is the estimated weekly stream temperature, $T_{a}$ is the average weekly air temperature, $\mu$ is the estimated minimum stream temperature, $\alpha$ is the estimated maximum stream temperature, $\gamma$ is a measure of the steepest slope of the function, and $\beta$ is the air temperature at the inflection point.

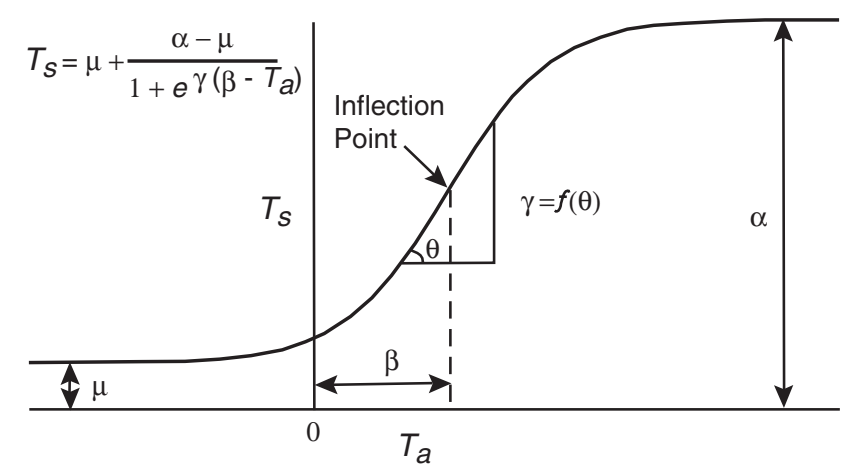

Figure 9. Schematic representation of the logistic function parameters (from Mohseni and others, 1998). 
At air temperatures below $0^{\circ} \mathrm{C}$, the regression line for water temperature levels out at $0^{\circ} \mathrm{C}$, as does observed water temperature before water undergoes a phase change into a solid; on the other end, the regression line flattens out, reflecting the process of evaporative cooling. Hysteresis is accounted for by separating the regression into two functions that represent rising and falling temperatures. (Hysteresis is the tendency for stream-temperature increases to lag airtemperature increases and for stream-temperature decreases to lag air-temperature decreases.) The rising limb function is used for the period starting the week in which the mean air temperature is at a minimum and ending the week in which the mean air temperature is at a maximum. The falling limb function then begins and lasts until the mean air temperature is at a minimum. The model was tested and provided acceptable results for 584 USGS sites (Mohseni and others, 1999).

Mohseni's model was used for this study, although in cooler climates such as Alaska the characteristics that make the nonlinear-regression model more accurate than a linear-regression model might be diminished. The largest deviations of observed temperatures from temperatures simulated by the model occurred at air temperatures above $0^{\circ} \mathrm{C}$ and below $12^{\circ} \mathrm{C}$. Air temperatures in Alaska tend to fall in this temperature range at a higher frequency than air temperatures in the 48 contiguous States. In areas with significant snowmelt, air- and watertemperature data are less correlated. Also, the presence of glaciers in the watershed may exacerbate this phenomenon (Mohseni and Stefan, 1999).

Ice, snow, and glaciers are prominent in Alaska and may influence the insensitivity of some runoff to air-temperature changes (Smith and Lavis, 1975;
Kobayashi, 1985; Webb and Noblis, 1997). Finally, air temperatures in Alaska may not warm sufficiently to register the signature from evaporative cooling and thus necessitate an S-shaped logistic function (Crisp and Howson, 1982; Mohseni and Stefan, 1999).

\section{Calibration and Verification}

Daily mean, maximum, and minimum airtemperature information were acquired from the National Climate Data Center (no date) for seven climate stations (table 3 ). The overall period of record spanned the years 1957 through 2000. Individual airtemperature records contained a minimum of 3 years of data, a maximum of 43 years of data, and a median of 29 years of data. Air temperatures of these seven climate stations ranged from $-34^{\circ} \mathrm{C}$ to $32^{\circ} \mathrm{C}$.

Water- and air-temperature data were compiled and converted into mean weekly temperatures. Mean weekly temperatures were computed using the Julian Day calendar year, where day 1 is January 1 and December 31 is either day 365 or day 366 , depending on whether a year is a leap year. The last week of the year comprises the normal 7-day week plus the remaining 1 or 2 days, for a total of 8 or 9 days. Data were not used if there were more than two daily measurements missing from each week. The number of weekly temperature-data values for each site ranged from 22 (at site 83) to 573 (at site 70) with a median of 67 weeks (table 4). Initially, the nearest air-temperature site was used for a given water-temperature site. If the results from the watertemperature model were not satisfactory, the next closest air-temperature site was used, because the data from the next closest site might better reflect the weather patterns that exist at the water-temperature site owing to factors such as topographic effects.

Table 3. Climate stations used with water-temperature-regression model [Source: National Climate Data Center (no date); ft, feet]

\begin{tabular}{|c|c|c|c|c|c|}
\hline $\begin{array}{l}\text { Map number } \\
\text { (figure 1) }\end{array}$ & Station name & $\begin{array}{c}\text { Elevation } \\
\text { (ft) }\end{array}$ & Latitude & Longitude & $\begin{array}{l}\text { Period of } \\
\text { record used }\end{array}$ \\
\hline 1 & Anchorage & 114 & $61^{\circ} 11^{\prime} 00^{\prime \prime}$ & $150^{\circ} 00^{\prime} 00^{\prime \prime}$ & 1969-2000 \\
\hline 2 & Cantwell & 655 & $63^{\circ} 24^{\prime} 00^{\prime \prime}$ & $148^{\circ} 54^{\prime} 00^{\prime \prime}$ & 1983-1986 \\
\hline 3 & Chulitna River Lodge & 427 & $62^{\circ} 49^{\prime} 00^{\prime \prime}$ & $149^{\circ} 54^{\prime} 00^{\prime \prime}$ & 1970-2000 \\
\hline 4 & Gulkana & 478 & $62^{\circ} 09^{\prime} 00^{\prime \prime}$ & $145^{\circ} 27^{\prime} 00^{\prime \prime}$ & 1996-2000 \\
\hline 5 & Homer & 27 & $59^{\circ} 39^{\prime} 00^{\prime \prime}$ & $151^{\circ} 29^{\prime} 00^{\prime \prime}$ & 1979-2000 \\
\hline 6 & Kenai & 84 & $60^{\circ} 35^{\prime} 00^{\prime \prime}$ & $151^{\circ} 14^{\prime} 00^{\prime \prime}$ & 1969-2000 \\
\hline 7 & Talkeetna & 105 & $62^{\circ} 19^{\prime} 00^{\prime \prime}$ & $150^{\circ} 06^{\prime} 00^{\prime \prime}$ & $1957-2000$ \\
\hline
\end{tabular}


Table 4. Results from water-temperature-regression model

[Values are for the open-water period, mid-May to mid-October; ${ }^{\circ} \mathrm{C}$, degrees Celsius; $\mathrm{AK}$, Alaska]

\begin{tabular}{|c|c|c|c|c|c|c|c|c|c|}
\hline $\begin{array}{c}\text { Map } \\
\text { number } \\
\text { (figure 1) }\end{array}$ & Station name & $\begin{array}{c}\text { Observed } \\
\text { minimum } \\
\text { weekly water } \\
\text { temperature } \\
\left({ }^{\circ} \mathrm{C}\right)\end{array}$ & $\begin{array}{c}\text { Observed } \\
\text { maximum } \\
\text { weekly water } \\
\text { temperature } \\
\left({ }^{\circ} \mathrm{C}\right)\end{array}$ & $\begin{array}{c}\text { Observed } \\
\text { mean air } \\
\text { temperature } \\
\left({ }^{\circ} \mathrm{C}\right)\end{array}$ & $\begin{array}{l}\text { Observed } \\
\text { mean water } \\
\text { temperature } \\
\left({ }^{\circ} \mathrm{C}\right)\end{array}$ & $\begin{array}{l}\text { Number } \\
\text { of weeks } \\
\text { of data }\end{array}$ & $\begin{array}{l}\text { Nash- } \\
\text { Sutcliffe } \\
\text { coefficient }\end{array}$ & $\begin{array}{l}\text { Root mean } \\
\text { square } \\
\text { error }\end{array}$ & Hysteresis \\
\hline 3 & $\begin{array}{l}\text { Bradley River near } \\
\text { Homer, AK }\end{array}$ & 0.0 & 11.1 & 9.5 & 6.0 & 219 & 0.68 & 1.94 & Yes \\
\hline 70 & $\begin{array}{l}\text { Bradley River near } \\
\text { tidewater near } \\
\text { Homer, AK }\end{array}$ & 0.0 & 11.9 & 9.6 & 6.5 & 573 & .93 & .94 & Yes \\
\hline 7 & $\begin{array}{l}\text { Ninilchik River at } \\
\text { Ninilchik, AK }\end{array}$ & 0.0 & 14.3 & 6.1 & 8.1 & 64 & .93 & 1.25 & Yes \\
\hline 82 & $\begin{array}{l}\text { Nikolai Creek near } \\
\text { Kasilof, AK }\end{array}$ & 0.0 & 12.8 & 9.2 & 5.2 & 87 & .64 & 2.28 & Yes \\
\hline 55 & $\begin{array}{l}\text { Kenai River below } \\
\text { Skilak Lake outlet } \\
\text { near Sterling, AK }\end{array}$ & 0.0 & 12.4 & 8.0 & 9.4 & 51 & .93 & 1.27 & Yes \\
\hline 16 & $\begin{array}{l}\text { Kenai River at } \\
\text { Soldotna, AK }\end{array}$ & 0.0 & 12.6 & 7.5 & 9.1 & 67 & .91 & 1.36 & Yes \\
\hline 17 & $\begin{array}{l}\text { Beaver Creek near } \\
\text { Kenai, AK }\end{array}$ & 0.0 & 12.6 & 8.6 & 7.6 & 232 & .92 & 1.24 & Yes \\
\hline 48 & $\begin{array}{l}\text { Chuitna River near } \\
\text { Tyonek, AK }\end{array}$ & 0.0 & 16.6 & 9.1 & 8.6 & 74 & .80 & 2.38 & No \\
\hline 23 & $\begin{array}{l}\text { South Fork Campbell } \\
\text { Creek near } \\
\text { Anchorage, AK }\end{array}$ & 0.0 & 10.7 & 10.1 & 6.5 & 48 & .98 & .60 & Yes \\
\hline 27 & $\begin{array}{l}\text { Chester Creek at } \\
\text { Arctic Boulevard at } \\
\text { Anchorage, AK }\end{array}$ & 0.0 & 14.9 & 10.4 & 9.7 & 285 & .97 & .87 & No \\
\hline 29 & $\begin{array}{l}\text { Ship Creek below power- } \\
\text { plant at Elmendorf Air Force } \\
\text { Base at Anchorage, AK }\end{array}$ & 0.2 & 15.9 & 10.4 & 9.0 & 438 & .75 & 1.60 & Yes \\
\hline 46 & $\begin{array}{l}\text { Susitna River at } \\
\text { Susitna Station, AK }\end{array}$ & 0.2 & 14.2 & 12.2 & 10.3 & 93 & .92 & .70 & No \\
\hline 83 & $\begin{array}{l}\text { Susitna River above } \\
\text { Yentna River near } \\
\text { Susitna Station, AK }\end{array}$ & 0.0 & 11.8 & 12.2 & 8.6 & 22 & .98 & .47 & No \\
\hline 43 & $\begin{array}{l}\text { Deception Creek near } \\
\text { Willow, AK }\end{array}$ & 0.0 & 14.1 & 10.1 & 7.8 & 127 & .90 & 1.45 & Yes \\
\hline 42 & $\begin{array}{l}\text { Willow Creek near } \\
\text { Willow, AK }\end{array}$ & 0.1 & 12.7 & 10.3 & 7.1 & 149 & .84 & 1.46 & No \\
\hline
\end{tabular}


Table 4. Results from water-temperature-regression model-Continued

[Values are for the open-water period, mid-May to mid-October; ${ }^{\circ} \mathrm{C}$, degrees Celsius; AK, Alaska]

\begin{tabular}{|c|c|c|c|c|c|c|c|c|c|}
\hline $\begin{array}{c}\text { Map } \\
\text { number } \\
\text { (figure 1) }\end{array}$ & Station name & $\begin{array}{l}\text { Observed } \\
\text { minimum } \\
\text { weekly water } \\
\text { temperature } \\
\left({ }^{\circ} \mathrm{C}\right)\end{array}$ & $\begin{array}{l}\text { Observed } \\
\text { maximum } \\
\text { weekly water } \\
\text { temperature } \\
\left({ }^{\circ} \mathrm{C}\right)\end{array}$ & $\begin{array}{c}\text { Observed } \\
\text { mean air } \\
\text { temperature } \\
\left({ }^{\circ} \mathrm{C}\right)\end{array}$ & $\begin{array}{c}\text { Observed } \\
\text { mean water } \\
\text { temperature } \\
\left({ }^{\circ} \mathrm{C}\right)\end{array}$ & $\begin{array}{l}\text { Number } \\
\text { of weeks } \\
\text { of data }\end{array}$ & $\begin{array}{l}\text { Nash- } \\
\text { Sutcliffe } \\
\text { coefficient }\end{array}$ & $\begin{array}{l}\text { Root mean } \\
\text { square } \\
\text { error }\end{array}$ & Hysteresis \\
\hline 44 & $\begin{array}{l}\text { Deshka River near } \\
\text { Willow, AK }\end{array}$ & 0.0 & 20.6 & 13.4 & 10.8 & 57 & 0.84 & 2.62 & No \\
\hline 84 & $\begin{array}{l}\text { Camp Creek near } \\
\text { Sheep Mountain } \\
\text { Lodge, AK }\end{array}$ & 0.0 & 6.9 & 9.2 & 3.4 & 122 & .68 & 1.17 & Yes \\
\hline 85 & $\begin{array}{l}\text { Susitna River at } \\
\text { Sunshine, AK }\end{array}$ & 0.2 & 12.1 & 9.0 & 7.7 & 29 & .97 & .61 & No \\
\hline 41 & $\begin{array}{l}\text { Talkeetna River near } \\
\text { Talkeetna, AK }\end{array}$ & 0.2 & 11.2 & 9.8 & 7.6 & 28 & .96 & .64 & No \\
\hline 86 & $\begin{array}{l}\text { Susitna River near } \\
\text { Talkeetna, AK }\end{array}$ & 0.2 & 13.3 & 10.8 & 9.3 & 33 & .95 & .80 & No \\
\hline 40 & $\begin{array}{l}\text { Chulitna River near } \\
\text { Talkeetna, AK }\end{array}$ & 0.2 & 8.5 & 11.3 & 5.8 & 67 & .66 & .98 & No \\
\hline 87 & $\begin{array}{l}\text { Susitna River at } \\
\text { Curry, AK }\end{array}$ & 1.1 & 14.1 & 11.0 & 9.5 & 28 & .95 & .72 & No \\
\hline 88 & $\begin{array}{l}\text { Oshetna River near } \\
\text { Cantwell, AK }\end{array}$ & 0.8 & 12.2 & 11.0 & 8.1 & 30 & .95 & .73 & Yes \\
\hline 89 & $\begin{array}{l}\text { Goose Creek near } \\
\text { Eureka, AK }\end{array}$ & 0.4 & 12.2 & 9.7 & 7.4 & 27 & .90 & 1.26 & No \\
\hline 38 & $\begin{array}{l}\text { Susitna River near } \\
\text { Cantwell, AK }\end{array}$ & 0.0 & 11.8 & 10.8 & 8.1 & 100 & .98 & .68 & No \\
\hline 39 & $\begin{array}{l}\text { Susitna River at } \\
\text { Gold Creek, AK }\end{array}$ & 0.1 & 12.6 & 10.4 & 8.1 & 96 & .84 & 1.48 & No \\
\hline 90 & $\begin{array}{l}\text { Kosina Creek near } \\
\text { Cantwell, AK }\end{array}$ & 0.1 & 12.7 & 10.8 & 8.4 & 26 & .94 & .95 & No \\
\hline 93 & $\begin{array}{l}\text { Indian River near } \\
\text { Gold Creek, AK }\end{array}$ & 1.6 & 11.9 & 11.2 & 7.4 & 30 & .80 & 1.24 & Yes \\
\hline 91 & $\begin{array}{l}\text { Watana Creek near } \\
\text { Cantwell, AK }\end{array}$ & 0.6 & 11.5 & 11.1 & 7.4 & 28 & .94 & .80 & No \\
\hline 92 & $\begin{array}{l}\text { Portage Creek near } \\
\text { Gold Creek, AK }\end{array}$ & 1.0 & 11.6 & 11.0 & 6.5 & 30 & .75 & 1.27 & Yes \\
\hline 36 & $\begin{array}{l}\text { Susitna River near } \\
\text { Denali, AK }\end{array}$ & 0.0 & 8.4 & 11.2 & 5.0 & 163 & .68 & 1.08 & No \\
\hline 109 & $\begin{array}{l}\text { Yentna River near } \\
\text { Susitna Station, AK }\end{array}$ & 1.3 & 11.8 & 11.7 & 8.5 & 85 & .81 & .92 & Yes \\
\hline
\end{tabular}


Regression equations were determined for each of the stream sites by using the formatted weekly stream- and air-temperature data as input to the model developed by Mohseni and others (1998). The observed and simulated data were then visually and statistically interpreted and analyzed. The NashSutcliffe coefficient (NSC) (Nash and Sutcliffe, 1970; Mohseni and others, 1998) was the main determinant of goodness of fit, and can be considered the proportion of variation explained:

$$
N S C=1-\frac{\sum_{i=1}^{n}\left(T_{\text {sim }_{i}}-T_{o b s_{i}}\right)^{2}}{\sum_{i=1}^{n}\left(\bar{T}_{o b s}-T_{o b s_{i}}\right)^{2}},
$$

where

NSC is the Nash-Sutcliffe coefficient,

$T_{\text {sim }}$ is the simulated water temperature,

$T_{o b s}$ is the observed water temperature, and

$\bar{T}_{o b s}$ is the mean observed water temperature.

Root mean squared error (RMSE) expresses the standard error of prediction and was also evaluated:

$$
R M S E=\sqrt{\frac{\sum_{i=1}^{n}\left(T_{\text {sim }_{i}}-T_{\text {obs }}\right)^{2}}{n-4}}
$$

However, the RMSE statistic was used cautiously because outliers can have a large effect on the value. A perfect correlation between observed and simulated data would have a NSC of 1 and a RMSE of zero.

For most stations, the period of weekly temperatures was from mid-May to mid-October, the openwater season. Thus, the water-temperature model was applied only to this period of data. Most stations had minimum weekly water temperatures between 0 and $1^{\circ} \mathrm{C}$ (table 4). Ship Creek (site 29), located downstream from a powerplant outfall, was within this range for 1 week, although most of the weekly minimum water temperatures were above $1^{\circ} \mathrm{C}$. Maximum weekly water temperature during the open-water period showed a wide variation, from $6.9^{\circ} \mathrm{C}$ at Camp Creek (site 84) to $20.6^{\circ} \mathrm{C}$ at the Deshka River (site 80). Comparisons of the average air and water temperatures for the open-water season indicate that the three sites with 25 percent or more of their upstream drainage area consisting of glaciers (Bradley River [site 3],
Chulitna River [site 40], Susitna River near Denali [site 36]) are on some of the coldest rivers, although the air temperature for the associated climate site was near the average. The sites with the highest mean water temperature were on Chester Creek (site 27), the urbanized stream in Anchorage; the Susitna River near Susitna Station (site 46), near the mouth of the Susitna River; and the Deshka River (site 80), a river that drains extensive wetlands.

The NSC ranged from 0.64 to 0.98 (table 4); 26 sites had a NSC of 0.75 or higher, which indicates a good fit between predicted and observed stream temperatures. Five sites had an NSC between 0.64 and 0.68 . The average distance between a watertemperature site and a climatological station was 35.4 miles. The closest air- and water-temperature stations were 3.1 miles apart, and 98.8 miles separated the most distant paired stations. Distance between airand water-temperature stations did not substantially influence the quality of fit of the water-temperatureregression model (fig. 10).

Sites in glaciated stream basins were relatively evenly distributed throughout the study area. The glacial streams examined have from 5 to 36 percent of their drainage basins covered by glaciers. Three sites, Bradley River (site 3), the Chulitna River (site 40), and the Susitna River near Denali (site 36), have 25 percent or more of their upstream drainage basins covered by glaciers. These streams have some of the lowest average water temperatures for the openwater period, most likely due to the large amount of glacial meltwater that enters the rivers. Nash-Sutcliffe coefficients for these three sites were relatively low$0.68,0.66$, and 0.68 , respectively (table 4 ). In general, with decreasing glacial coverage, the effects from glaciers on water temperature are diminished, and the Nash-Sutcliffe coefficients are higher (fig. 11).

Forty-seven percent, or 15 of the 32 sites, exhibited hysteresis (table 4). This figure is similar to the 43 percent of the streams in the contiguous United States that exhibit noticeable hysteresis (Mohseni and others, 1998). The majority of sites exhibiting hysteresis were located in the Kenai Peninsula. Ship Creek below the powerplant at Elmendorf Air Force Base (Site 29) is an example of extreme hysteresis (fig. 12). Some possible reasons for hysteresis are the melting of the snowpack during the spring, which results in cold water entering a stream as air temperature rises, or the input of warm water from a powerplant during the winter season, which maintains artificially warmer water temperatures as the air temperature falls. 


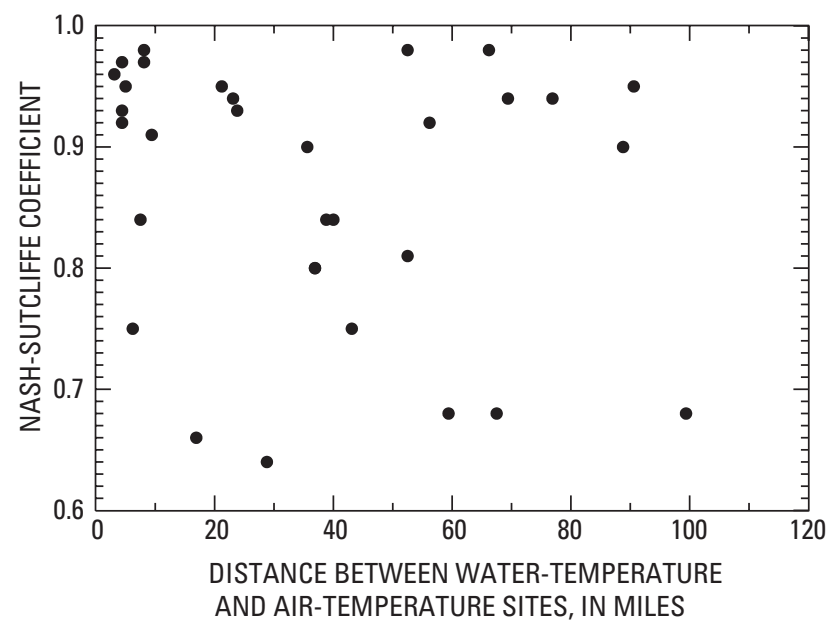

Figure 10. Relation of distance between a watertemperature site and its associated air-temperature site to Nash-Sutcliffe coefficient.

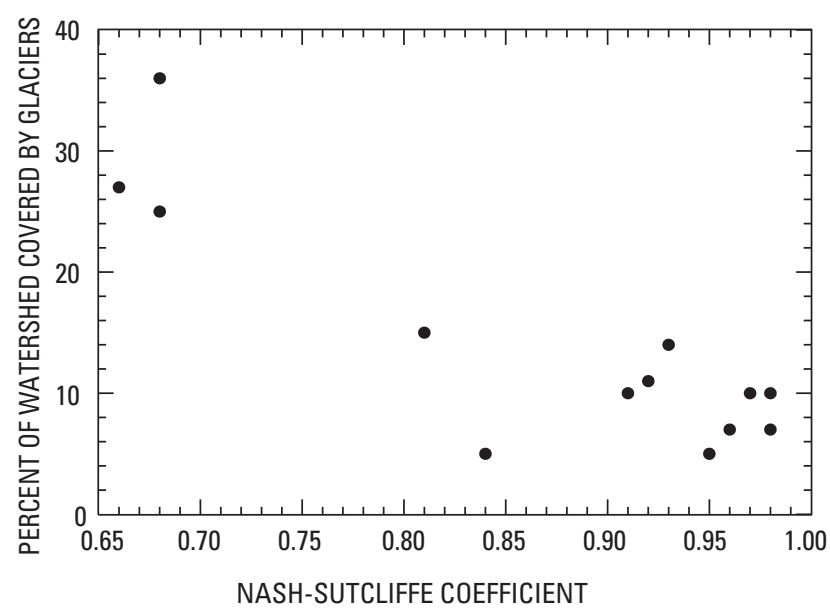

Figure 11. Relation between percent of watershed covered by glaciers and Nash-Sutcliffe coefficient.

The regression-model parameters are shown in table 5. Compared to the study by Mohseni and others (1998), air temperature at the inflection point ( $\beta$, [fig. 9 and eq. 1]) and the steepest slope $(\gamma)$ varied more in Alaska. The estimated minimum stream temperature $(\mu)$ was less varied because most streams cool to near $0^{\circ} \mathrm{C}$. A typical example is site 10 , Chester Creek at Arctic Boulevard at Anchorage (fig. 13). The plot for the simulated water temperature exhibits the typical S-shaped curve, starting at $0^{\circ} \mathrm{C}$ and then decreasing in slope at higher temperatures as the effects of evaporative cooling begin. Regression equations with the lowest quality of fit were, on average, for cooler streams.

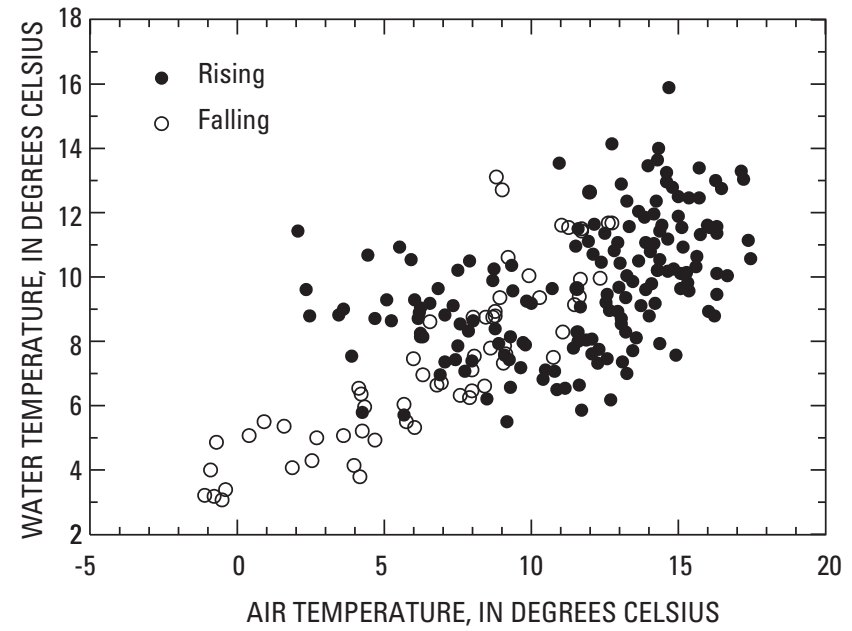

Figure 12. Relation between weekly average water temperature and weekly average air temperature for Ship Creek below powerplant at Elmendorf Air Force Base at Anchorage, Alaska.

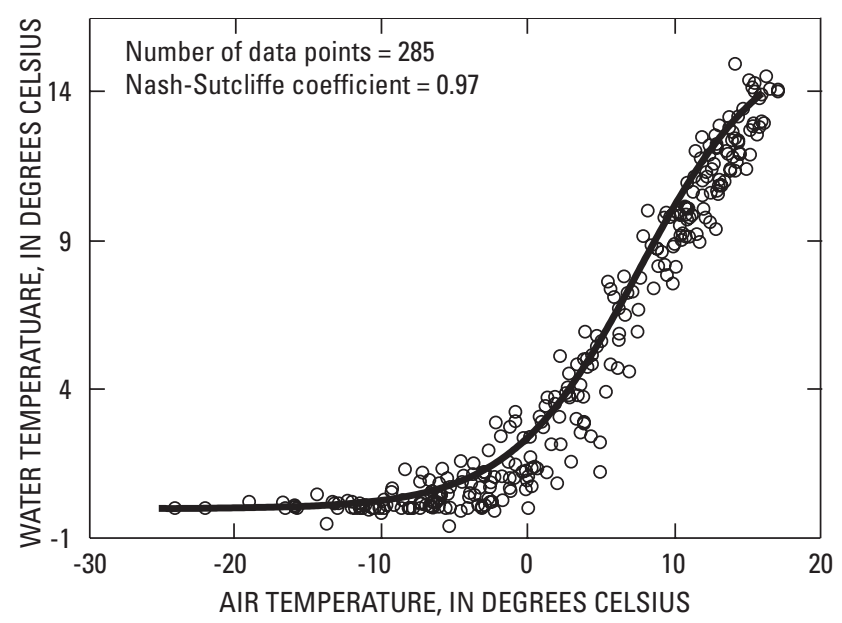

Figure 13. Relation between weekly average water temperature and weekly average air temperature for Chester Creek at Arctic Boulevard at Anchorage, Alaska.

\section{Stream-Temperature Projections and Implications}

According to the Canadian Climate Model and the Hadley Center Model, the largest increases in air temperature will occur during the winter, and only modest increases will occur during the summer. The mean annual increase will be $7.2^{\circ} \mathrm{C}$ in the northern half of the Cook Inlet Basin and $8.5^{\circ} \mathrm{C}$ for western Cook Inlet and the Kenai Peninsula. Both models assume a doubling of carbon dioxide. The predicted air-temperature increases were added to the air-temperature records used at each site, and the predicted stream temperatures were determined by use of the regression equations determined by the water-temperature model. Only the 27 sites with an NSC of 0.75 or higher were used. 
Table 5. Water-temperature regression-model parameters

[All values in degrees Celsius $\left({ }^{\circ} \mathrm{C}\right)$; AK, Alaska]

\begin{tabular}{|c|c|c|c|c|c|}
\hline $\begin{array}{c}\text { Map } \\
\text { number } \\
\text { (figure 1) }\end{array}$ & Station name & $\begin{array}{l}\text { alpha, } \alpha \\
\quad\left({ }^{\circ} \mathbf{C}\right)\end{array}$ & $\begin{array}{l}\text { beta, } \beta \\
\left({ }^{\circ} \mathbf{C}\right)\end{array}$ & $\begin{array}{l}\text { gamma, } \gamma \\
\left({ }^{\circ} \mathrm{C}\right)\end{array}$ & $\begin{array}{c}\mathrm{mu}, \mu \\
\left({ }^{\circ} \mathbf{C}\right)\end{array}$ \\
\hline 3 & Bradley River near Homer, AK & 12.8 & 18.4 & 0.1 & 0 \\
\hline 70 & Bradley River near tidewater near Homer, AK & 13.1 & 12.0 & 0.3 & 0.3 \\
\hline 7 & Ninilchik River at Ninilchik, AK & 14.5 & 6.6 & 0.6 & 0 \\
\hline 82 & Nikolai Creek near Kasilof, AK & 16.4 & 11.6 & 0.3 & 0 \\
\hline 55 & Kenai River below Skilak Lake outlet near Sterling, AK & 12.4 & 7.0 & 0.5 & 1.0 \\
\hline 16 & Kenai River at Soldotna, AK & 14.3 & 8.9 & 0.3 & 0 \\
\hline 17 & Beaver Creek near Kenai, AK & 13.7 & 7.5 & 0.3 & 0 \\
\hline 48 & Chuitna River near Tyonek, AK & 18.7 & 10.0 & 0.3 & 0 \\
\hline 23 & South Fork Campbell Creek near Anchorage, AK & 10.9 & 10.3 & 0.3 & 0.1 \\
\hline 27 & Chester Creek at Arctic Boulevard at Anchorage, AK & 16.0 & 8.6 & 0.2 & 0 \\
\hline 29 & $\begin{array}{l}\text { Ship Creek below powerplant at Elmendorf } \\
\text { Air Force Base at Anchorage, AK }\end{array}$ & 17.0 & 11.1 & 0.1 & 1.6 \\
\hline 46 & Susitna River at Susitna Station, AK & 16.0 & 8.9 & 0.2 & 0 \\
\hline 83 & $\begin{array}{l}\text { Susitna River above Yentna River near } \\
\text { Susitna Station, AK }\end{array}$ & 13.0 & 7.1 & 0.2 & 0 \\
\hline 43 & Deception Creek near Willow, AK & 16.1 & 11.9 & 0.3 & 0 \\
\hline 42 & Willow Creek near Willow, AK & 14.3 & 10.6 & 0.2 & 0.1 \\
\hline 44 & Deshka River near Willow, AK & 27.1 & 18.1 & 0.2 & 0 \\
\hline 84 & Camp Creek near Sheep Mountain Lodge, AK & 7.5 & 11.0 & 0.2 & 0.1 \\
\hline 85 & Susitna River at Sunshine, AK & 12.5 & 7.1 & 0.3 & 0 \\
\hline 41 & Talkeetna River near Talkeetna, AK & 11.8 & 7.0 & 0.2 & 0 \\
\hline 86 & Susitna River near Talkeetna, AK & 13.8 & 7.8 & 0.3 & 0 \\
\hline 40 & Chulitna River near Talkeetna, AK & 9.4 & 7.7 & 0.2 & 0 \\
\hline 87 & Susitna River near Curry, AK & 16.1 & 9.4 & 0.2 & 0 \\
\hline 88 & Oshetna River near Eureka, AK & 13.5 & 11.3 & 0.2 & 0 \\
\hline 89 & Goose Creek near Eureka, AK & 13.1 & 9.2 & 0.3 & 0.1 \\
\hline 38 & Susitna River near Cantwell, AK & 12.6 & 8.1 & 0.2 & 0 \\
\hline 39 & Susitna River at Gold Creek, AK & 13.8 & 9.7 & 0.2 & 1.1 \\
\hline 90 & Kosina Creek near Eureka, AK & 13.6 & 9.3 & 0.3 & 0 \\
\hline 93 & Indian River near Gold Creek, AK & 13.8 & 12.5 & 0.3 & 0 \\
\hline 91 & Watana Creek near Gold Creek, AK & 12.5 & 10.1 & 0.3 & 0 \\
\hline 92 & Portage Creek near Gold Creek, AK & 16.0 & 18.0 & 0.1 & 0 \\
\hline 36 & Susitna River near Denali, AK & 9.5 & 10.5 & 0.2 & 0 \\
\hline 109 & Yentna River near Susitna Station, AK & 12.7 & 8.2 & 0.2 & 0 \\
\hline
\end{tabular}


Similar to the method used by Mohseni and others (1999), an error analysis was conducted. There are errors associated with the projection of air temperatures by the General Circulation Models and errors in the stream-model simulations. The error analysis was a one-tail paired Student's $t$ test at the 95 percent confidence level between the mean of the errors for water temperature:

$$
\chi_{1}=\frac{1}{n} \underset{i=1}{\sum}\left|T_{\text {sim }_{i}}-T_{\text {obs }}\right|,
$$

where

$T_{\text {sim }}=$ simulated water temperature,

$T_{o b s}=$ observed water temperature,

and the means of the changes under the $2 \times \mathrm{CO}_{2}$ climate scenario:

$$
\chi_{2}=\frac{1}{n} \underset{i=1}{n}\left|T_{\text {sim }_{i}}-T_{2 \times \mathrm{CO}_{2}}\right| \text {, }
$$

where

$\mathrm{T}_{2} \times \mathrm{CO}_{2}=$ water temperature under the $2 \times \mathrm{CO}_{2}$ climate scenario. If the $t$ test failed at the 95 percent level, then the site has significant changes in stream temperature under the $2 \times \mathrm{CO}_{2}$ climate scenario.

Results from the climate-change simulation indicate that mean water temperature for all the sites would increase (table 6). Differences between mean observed and climate-change water temperatures range from $1.2^{\circ} \mathrm{C}$ at site 23 to $7.1^{\circ} \mathrm{C}$ at site 48 . The changes in weekly minimum water temperature ranged from $0.0^{\circ} \mathrm{C}$ to $6.4^{\circ} \mathrm{C}$. The regression model indicated that only one site, Deshka near Willow (site 44), would have a maximum weekly water temperature higher than $20^{\circ} \mathrm{C}$, but the observed temperature for that week was over $20^{\circ} \mathrm{C}$ as well. Results of the $t$ test indicated statistical significance for all 27 sites.

Fifteen sites had a difference of means between observed and climate-change water temperatures of more than $3^{\circ} \mathrm{C}$ (fig. 14), which is significant, according to Chatters and others (1991), in influencing the incidence of disease in fish. However, it should be noted that water-temperature changes would be gradual and fish might adapt to the $3^{\circ} \mathrm{C}$ change or might move to a cooler portion of the stream. A characteristic of sites with climate change equal to or greater than $3^{\circ} \mathrm{C}$ is that they are generally warmer, because there are fewer glaciers in their watersheds.

Fish survival depends on a number of factors, such as food supply, habitat conditions, predators, pathogens, and competitors (Regier and others, 1996). A temperature change greater than or $3^{\circ} \mathrm{C}$ in the Pacific Northwest is expected to increase the incidence of disease in fish (Chatters and others, 1991). It is unlikely that fatal temperatures for salmon will be reached in the Cook Inlet Basin with a doubling of carbon dioxide, but the incidence of infection within salmon fisheries may rise.

It is important to note that the climate-change estimations for streams are based on stream-temperature data from the open-water season and the assumption that there will be no future change in the physical setting of the stream (Mohseni and others, 1999). Three indirect factors affecting the change in stream temperature caused by global climate warming not considered by the water-temperature-regression model are (1) forest or vegetation cover change, (2) alternative sources of cooler or warmer water (i.e., natural and artificial reservoirs), and (3) precipitation. Forest cover affects stream temperatures by reducing the magnitude of extremes and reducing the seasonal variations in temperature (Johnson, 1971). If a basin is logged or the vegetation removed, studies have shown that significant increases in water temperature will occur (Brown and Krygier, 1970). Outflows from dams and lakes add water to stream systems that alter the heat balance equilibrium and reduce the sensitivity of the stream temperature to climatological changes. Increases in air temperature would most likely increase the temperature of ground water entering streams. Ripley (1987) hypothesized that the most direct effects of climate change on hydrological regimes will be through changes in precipitation. The hydrologic cycle will intensify and may change weather patterns, so some parts of the world will receive more rain and snow as other parts experience a decline in precipitation. In some areas, increased streamflow will enhance the thermal capacities of streams and make streams less susceptible to atmospheric conditions, and the reverse will be true for areas with decreased streamflow (Meisner, 1990). 
Table 6. Predicted water temperatures due to climate change [Values in degrees Celsius. AK, Alaska]

\begin{tabular}{|c|c|c|c|c|c|c|c|}
\hline $\begin{array}{c}\text { Map } \\
\text { number } \\
\text { (figure 1) }\end{array}$ & Station name & $\begin{array}{c}\text { Minimum } \\
\text { weekly } \\
\text { temperature }\end{array}$ & $\begin{array}{c}\text { Change in } \\
\text { minimum } \\
\text { temperature }\end{array}$ & $\begin{array}{c}\text { Maximum } \\
\text { weekly } \\
\text { temperature }\end{array}$ & $\begin{array}{c}\text { Change in } \\
\text { maximum } \\
\text { temperature }\end{array}$ & $\begin{array}{c}\text { Mean } \\
\text { water } \\
\text { temperature }\end{array}$ & $\begin{array}{l}\text { Change in } \\
\text { mean water } \\
\text { temperature }\end{array}$ \\
\hline 70 & $\begin{array}{l}\text { Bradley River near tidewater near } \\
\text { Homer, AK }\end{array}$ & 0.2 & 0.2 & 12.9 & 1.0 & 10.2 & 3.7 \\
\hline 7 & Ninilchik River at Ninilchik, AK & 0.0 & 0.0 & 14.5 & 0.2 & 13.4 & 5.3 \\
\hline 55 & $\begin{array}{l}\text { Kenai River below Skilak Lake } \\
\text { outlet near Sterling, AK }\end{array}$ & 1.0 & 1.0 & 12.4 & 0.0 & 11.8 & 2.4 \\
\hline 16 & Kenai River at Soldotna, AK & 0.0 & 0.0 & 13.9 & 1.3 & 11.5 & 2.4 \\
\hline 17 & Beaver Creek near Kenai, AK & 0.0 & 0.0 & 13.6 & 1.0 & 12.9 & 5.3 \\
\hline 48 & Chuitna River near Tyonek, AK & 0.1 & 0.1 & 18.3 & 1.7 & 15.7 & 7.1 \\
\hline 23 & $\begin{array}{l}\text { South Fork Campbell Creek near } \\
\text { Anchorage, AK }\end{array}$ & 1.2 & 1.2 & 9.4 & -1.3 & 7.7 & 1.2 \\
\hline 27 & $\begin{array}{l}\text { Chester Creek at Arctic Boulevard at } \\
\text { Anchorage, AK }\end{array}$ & 0.0 & 0.0 & 15.6 & 0.6 & 13.6 & 3.9 \\
\hline 29 & $\begin{array}{l}\text { Ship Creek below powerplant at Elmen- } \\
\text { dorf Air Force Base at Anchorage, AK }\end{array}$ & 4.0 & 3.8 & 12.2 & -3.7 & 10.8 & 1.8 \\
\hline 46 & Susitna River at Susitna Station, AK & 3.9 & 3.7 & 15.2 & 1.0 & 13.8 & 3.5 \\
\hline 83 & $\begin{array}{l}\text { Susitna River above Yentna River near } \\
\text { Susitna Station, AK }\end{array}$ & 3.5 & 3.5 & 12.6 & 0.8 & 11.3 & 2.7 \\
\hline 43 & Deception Creek near Willow, AK & 0.0 & 0.0 & 15.4 & 1.3 & 12.2 & 4.4 \\
\hline 42 & Willow Creek near Willow, AK & 0.3 & 0.2 & 13.6 & 0.9 & 11.4 & 4.3 \\
\hline 44 & Deshka River near Willow, AK & 0.1 & 0.1 & 24.6 & 4.0 & 16.2 & 5.4 \\
\hline 85 & Susitna River at Sunshine, AK & 0.5 & 0.3 & 12.3 & 0.2 & 10.4 & 2.7 \\
\hline 41 & Talkeetna River near Talkeetna, AK & 3.2 & 3.0 & 11.6 & 0.4 & 10.2 & 2.6 \\
\hline 86 & Susitna River near Talkeetna, AK & 0.5 & 0.3 & 13.6 & 0.3 & 11.9 & 2.6 \\
\hline 87 & Susitna River at Curry, AK & 6.9 & 5.8 & 15.4 & 1.3 & 13.7 & 4.2 \\
\hline 88 & Oshetna River near Cantwell, AK & 4.4 & 3.6 & 12.8 & 0.6 & 10.9 & 2.8 \\
\hline 89 & Goose Creek near Cantwell, AK & 3.7 & 3.3 & 13.0 & 0.8 & 11.3 & 3.9 \\
\hline 38 & Susitna River near Cantwell, AK & 0.0 & 0.0 & 12.4 & 0.6 & 11.0 & 2.9 \\
\hline 39 & Susitna River at Gold Creek, AK & 1.7 & 1.6 & 13.5 & 0.9 & 11.6 & 3.5 \\
\hline 90 & Kosina Creek near Cantwell, AK & 3.7 & 3.6 & 13.5 & 0.8 & 12.0 & 3.6 \\
\hline 93 & Indian River near Gold Creek, AK & 2.2 & 0.6 & 13.4 & 1.5 & 11.2 & 3.8 \\
\hline 91 & Watana Creek near Cantwell, AK & 3.1 & 2.5 & 12.3 & 0.8 & 10.8 & 3.3 \\
\hline 92 & Portage Creek near Gold Creek, AK & 3.8 & 2.8 & 10.3 & -0.2 & 8.1 & 1.6 \\
\hline 109 & Yentna River near Susitna Station, AK & 7.7 & 6.4 & 12.3 & 0.5 & 11.5 & 3.0 \\
\hline
\end{tabular}




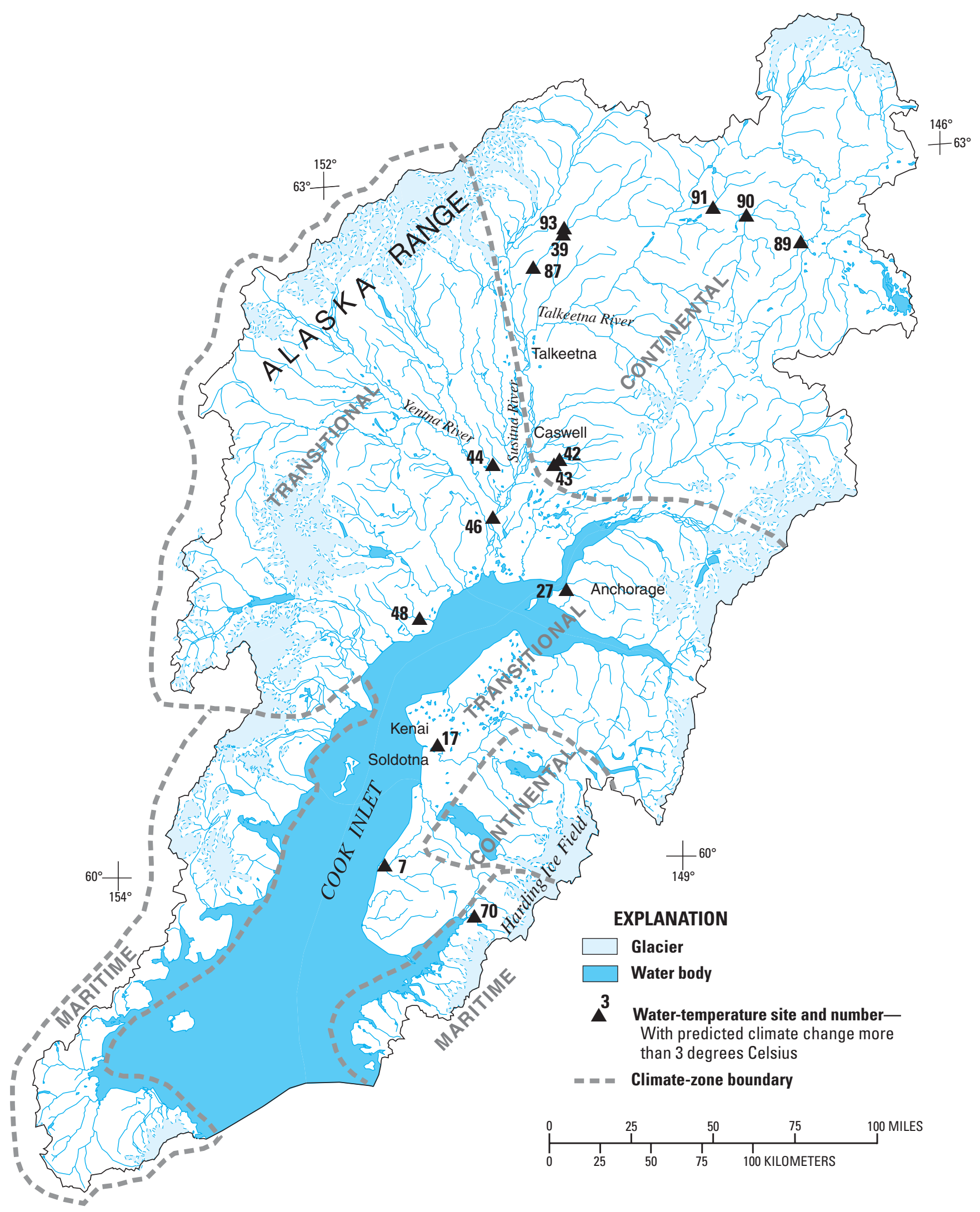

Figure 14. Water-temperature sites in the Cook Inlet Basin with predicted water temperatures greater than 3 degrees Celsius. 
Webb and Nobilis (1997) suggest that the relationship between air and river temperatures is better described as similar responses to seasonal changes of two mediums with slightly different thermal capacities. The nonlinear-regression model may describe the air-temperature dependency of water temperature, but little is explained. Air temperature may not be an adequate predictor of the effects of climate change on the stream environment (Jager and others, 1999), but using an air-temperature-based model may be a useful and simple way to estimate current and future water temperatures if all other variables are held constant.

Conversely, semiquantitative reviews of sparse climate data from more remote subarctic regions are important in contributing to the understanding of climate change as it affects the entire globe. Global warming is expected to be greatest at higher latitudes. Alaska has undergone the most climate warming of all the States in the United States since 1960 (Alaska Regional Assessment Group, 1999). Temperature modeling and estimation is also valuable for rough predictions of climate-change effects on the survival and distribution of organisms in local ecosystems. As models to predict effects of temperature upon freshwater communities (Brett, 1971; Baltz and others, 1987; Christie and Regier, 1988; Eaton and Scheller, 1996; Rombough, 1996; Scheller and others, 1999) are developed, the prediction of water temperatures in streams will become ever more important (Crisp and Howson, 1982). The use of temperature models is practical for filling in gaps of data and estimating past temperatures, as well as for predicting temperatures in succeeding years.

\section{SUMMARY}

Water temperature is a valuable measure and descriptor of physical, chemical, and biological characteristics of streams and rivers in the Cook Inlet Basin in south-central Alaska. Fish health and populations, in particular, are greatly affected by water-temperature conditions. Existing watertemperature data in the Cook Inlet Basin has been compiled and analyzed. Major findings are:

- Water temperature from sites in the Kenai Peninsula is dependent on basin characteristics. Streams and rivers such as Beaver Creek and the Ninilchik River that drain lowland areas have higher water temperatures than watersheds that contain glaciers, such as the Bradley River. The Kenai River downstream of Skilak Lake has higher water temperature in the winter than near its mouth at Soldotna.

- In the Anchorage area, South Fork Campbell Creek, which drains a relatively high elevation watershed, has the coldest water temperature; Chester Creek, an urbanized basin, has warmer temperatures; and Ship Creek, downstream from a powerplant, has the warmest temperatures in the winter.

- The Susitna River is the largest river in the Cook Inlet Basin. In the headwaters of the basin, glaciers dominate the basin, and, as a result, water temperatures during the openwater season remain at $8.5^{\circ} \mathrm{C}$ or lower. Proceeding downriver, the Susitna River gradually warms until it reaches the Chulitna and Talkeetna Rivers. The input from these two rivers lowers the water temperature. From this point, water temperature gradually increases.

- Mohseni and others (1998) developed a nonlinear-regression model for predicting water temperature from air temperature. The model was applied to data collected in the Cook Inlet Basin in Alaska. Twentyseven sites had a Nash-Sutcliffe coefficient of 0.75 or higher, indicating a good fit of the model. Sites on streams with greater than 25 percent of their basin consisting of glaciers produced a poor simulation because glacial meltwater keeps the streams cold in summer, when air temperatures are rising.

- Global circulation models predict air temperature increases of between $7.2^{\circ} \mathrm{C}$ and $8.5^{\circ} \mathrm{C}$ for the Cook Inlet Basin. These increased air temperatures were used as input to the temperature-regression equations developed for 27 sites to simulate future trends in water temperature. Fifteen sites had a predicted water-temperature change of $3^{\circ} \mathrm{C}$ or more, which is considered significant for the incidence of disease in fish populations. 


\section{REFERENCES CITED}

Alaska Department of Fish and Game, 1983, Susitna hydro aquatic studies phase II report: Susitna Hydro Aquatic Studies, v. 4.

Alaska Department of Fish and Game, 1984, Aquatic habitat and instream flow investigations (May-October 1983): Susitna Hydro Aquatic Studies Report Series 4.3.1.6, report no. 3, ch. 3 .

Alaska Regional Assessment Group, 1999, The potential consequences of climate variability and change - The center for global change and arctic system research: University of Fairbanks Alaska, 42 p.

Alderice, D.F., and Velsen, F.P.J., 1978, Relation between temperature and incubation time for eggs of chinook salmon (Oncorhynchus tshawytscha): Journal of the Fisheries Research Board of Canada, v. 35, p. 69-75.

Baltz, D.M., Vondracek, B., Brown, L.R., and Moyle, P.B., 1987, Influence of temperature on microhabitat choice by fishes in a California stream: Transaction of the American Fisheries Society, v. 116, p. 12-20.

Bell, M.C., 1973, Fisheries handbook of engineering requirements and biological criteria: Portland, Oregon, United States Army Corps of Engineers.

Brabets, T.P., Nelson, G.L., Dorava, J.M., and Milner, A.M., 1999, Water-quality assessment of the Cook Inlet Basin, Alaska-Environmental setting: U.S. Geological Survey Water-Resources Investigations Report 99-4025, 65 p.

Brett, J.R., 1971, Energetic responses of salmon to temperature-A study of some thermal relations in the physiology and freshwater ecology of sockeye salmon (Oncorhynchus nerka): American Zoology, v. 11, p. 99-113.

Brown, G.W., 1969, Predicting temperatures of small streams: Water Resources Research, v. 5, no. 1, p. $68-75$.

Brown, G.W., and Krygier, J.T., 1970, Effects of clearcutting on stream temperature: Water Resources Research, v. 6, no. 4, p. 1133-1139.

Canadian Centre for Climate Modeling and Analysis, no date: http://www.cccma.bc.ec.gc.ca, accessed June 1, 2000.

Carpenter, S.R., Fisher, S.G., Grimm, N.B., and Kitchell, J.F., 1992, Global change and freshwater ecosystems: Annual Reviews of Ecological Sustainability, v. 23, p. 119-139.

Chatters, J.C., Neitzel, D.A., Scott, M.J., and Shankle, S.A., 1991, Potential impacts of global climate change on Pacific Northwest chinook salmon (Oncorhynchus tshawytscha)_An exploratory case study: The Northwest Environmental Journal, v. 7, p. 71-92.
Christie, G.C., and Regier, H.A., 1988, Measures of optimal thermal habitat and their relationship to yields for four commercial fish species: Canadian Journal of Fisheries and Aquatic Science, v. 45, p. 301-314.

Crawshaw, L.I., and O'Connor, C.S., 1997, Behavioral compensation for long-term thermal change, in Wood, C.M., and McDonald, D.G., eds., Society for Experimental Biology Seminar Series 61, Global Warming-Implications for Freshwater and Marine Fish: Cambridge University Press, p. 351-376.

Crisp, D.T., and Howson, G., 1982, Effect of air temperature upon mean water temperature in streams in the North Pennines and English Lake District: Freshwater Biology, v. 12, p. 359-367.

Eaton, J.G., and Scheller, R.M., 1996, Effects of climate warming on fish thermal habitat in streams of the United States: Limnology and Oceanography, v. 41, no. 5, p. 1109-1115.

Edinger, J.E., Duttweiler, D.W., and Geyer, J.C., 1966, Some observations on stream temperature: Oikos, v. 15 , p. $265-273$.

Edwards, R.W., Densem, J.W., and Russell, P.A., 1979, An assessment of the importance of temperature as a factor controlling the growth rate of brown trout in streams: Journal of Animal Ecology, v. 1948, p. 501-507.

Glass, R.L., 1999, Water-quality assessment of the Cook Inlet Basin, Alaska-Summary of data through 1997: U.S. Geological Survey Water-Resources Investigations Report 99-4116, 110 p.

Groot, C., and Margolis, L. eds., 1991, Pacific salmon life histories: Vancouver, University of British Columbia Press, $564 \mathrm{p}$.

Hadley Centre for Climate Prediction and Research, no date: http://www.met-office.gov.uk/research/ hadleycentre/index.html, accessed June 1, 2000.

Hartman, C.W., and Johnson, P.R., 1978, Environmental Atlas of Alaska (2d ed.): Fairbanks, University of Alaska, Institute of Water Resources, 95 p.

Howe, A.L., Fidler, G., Olnes, C, Bingham, A.E., and Mills, M.J., 1998, Harvest, catch, and participation in Alaska sport fisheries during 1997: Alaska Department of Fish and Game, Fishery Data Series no. 98-25, 220 p.

Jager, H.I, Van Winkle, W., Holcomb, B.D., 1999, Would hydrological climate changes in Sierra Nevada streams influence trout persistence?: Transactions of the American Fisheries Society, v. 128, p. 222-240.

Johnson, F.A., 1971, Stream temperatures in an alpine area: Journal of Hydrology, v. 14, p. 322-336.

Kobayashi, D., 1985, Separation of the snowmelt hydrograph by stream temperatures: Journal of Hydrology, v. 76, p. 155-162. 
Magnuson, J.J., Meisner, J.D., and Hill, D.K., 1990, Potential changes in the thermal habitat of Great Lakes fish after global climate warming: Transactions of the American Fisheries Society, v. 119, p. 254-264.

McCormick, S.D., Shrimpton, J.M., and Zydlewski, J.D., 1996, Temperature effects on osmoregulatory physiology of juvenile anadromous fish, in Wood, C.M., and McDonald, D.G., eds, Society for experimental biology seminar series 61, Global warming-Implications for freshwater and marine fish: Cambridge University Press, p. 351-376.

Meisner, J.D., 1990, Potential loss of thermal habitat for brook trout, due to climatic warming, in two southern Ontario streams: Transactions of the American Fisheries Society, v. 119, p. 282-291.

Mohseni, O., Erickson, T.R., and Stefan, H.G., 1999, Sensitivity of stream temperatures in the United States to air temperatures projected under a global warming scenario: Water Resources Research, v. 35, no. 12, p. 3723-3733.

Mohseni, O., and Stefan, H.G., 1999, Stream temperature/ air temperature relationship: Journal of Hydrology, v. 218 , p. $128-141$.

Mohseni, O., Stefan, H.G., and Erickson, T.R., 1998, A nonlinear regression model for weekly stream temperatures: Water Resources Research, v. 34, no. 10, p. 2685-2692.

Murray, C.B., and McPhail, J.D., 1988, Effect of incubation temperature on the development of five species of Pacific salmon (Oncorhynchus) embryos and alevins: Canadian Journal of Zoology, v. 66, no. 1, p. 266-273.

Nash, J.E., and Sutcliffe, J.V., 1970, River flow forecasting through conceptual models: Journal of Hydrology, v. 10 , p. 282-290.

National Climate Data Center, no date: http://www.ncdc. noaa.gov, accessed November 1, 1999.

Peterson, R.H., Spinney, H.C.E., and Sreedharan, A., 1977, Development of Atlantic Salmon (Salmo salar) eggs and alevins under varied temperature regimes: Journal of the Fisheries Research Board of Canada, v. 34, p. $31-43$.

Pilgrim, J.M., Fang, X., and Stefan, H.G., 1998, Stream temperature correlations with air temperatures in Minnesota: implications for climate change: Journal of the American Water Resources Association, v. 34, no. 5, p. 1109-1121.

R\&M Consultants, Inc., 1981, Water quality annual report 1981, Alaska Power Authority Susitna Hydroelectric Project, task 3-Hydrology: Anchorage, 152 p.
Regier, H.A., Lin, P., Ing, K.K., and Wichert, G.A., 1996, Likely responces to climate change of fish associations in the Laurentian Great Lakes Basin-Concepts, methods, and findings: Boreal Environment Research, v. 1, p. 1-15.

Ripley, E.A., 1987, Climate change and the hydrological regime, in Healey, M.C., and Wallace, R.R., eds., Canadian aquatic resources: Ottowa, Canada, The Rawson Academy of Aquatic Science, p. 137-178.

Rombough, P.J., 1996, The effects of temperature on embryonic and larval development, in Wood, C.M., and McDonald, D.G., eds, Society for experimental biology seminar series 61, Global warming-Implications for freshwater and marine Fish: Cambridge University Press, p. 351-376.

Scheller, R.M., Snarski, V.I., Eaton, J.G., Oehlert, G.W., 1999, An analysis of the influence of annual thermal variables on the occurrence of fifteen warmwater fishes: Transaction of the American Fisheries Society, v. 128 , p. 257-264.

Shuter, B.J., and Post, J.R., 1990, Climate, population, viability, and zoogeography of temperate fishes: Transactions of the American Fisheries Society, v. 119, p. 314-336.

Sinokrot, B.A., and Stefan, H.G., 1993, Stream temperature dynamics: Water Resources Research, v. 29, no. 7, p. 2299-2312.

Smith, K., 1972, River water temperatures: Scottish Geographical Magazine, v. 88, p. 211-220.

Smith, K., and Lavis, M.E., 1975, Environmental influences on the temperature of a small upland stream: Oikos, v. 26, p. $228-236$.

Song, C.C.S., Pabst, A F., and Bowers, C.F., 1973, Stochastic analysis of air and water temperatures: Journal of the Environmental Engineering Division, v. 99 , p. $785-800$.

Stefan, H.G., and Preud'homme, E.B., 1993, Stream temperature estimation from air temperature: Water Resources Bulletin, v. 29, no. 1, p. 27-45.

U.S. Environmental Protection Agency, 1976, Quality citeria for water: Washington, D.C., EPA/400/9-76-023.

Ward, J.C., 1963, Annual variation of stream water temperature: Journal of the Sanitary Engineering Division, Proceedings of the American Society of Civil Engineers, v. 89, no. SA 6, p. 1-16.

Webb, B.W., and Nobilis, F., 1997, Long-term perspective on the nature of the air-water temperature relationship; a case study: Hydrological Processes, v. 11, p. 137-147. 